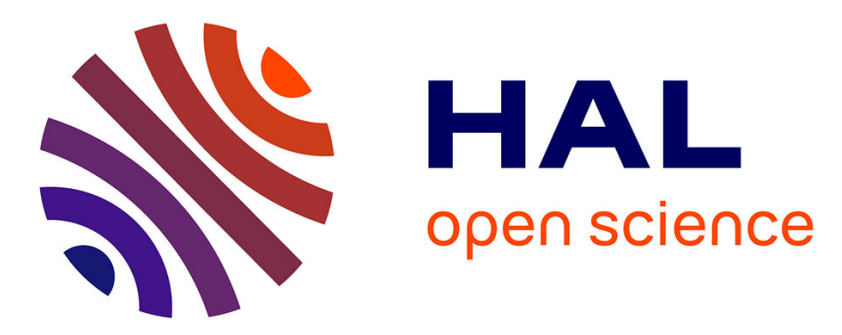

\title{
Hygric and thermal properties of hemp-lime plasters
}

Brahim Mazhoud, Florence Collet, Sylvie Pretot, Julien Chamoin

\section{To cite this version:}

Brahim Mazhoud, Florence Collet, Sylvie Pretot, Julien Chamoin. Hygric and thermal properties of hemp-lime plasters. Building and Environment, 2016, 96, pp.206-216. 10.1016/j.buildenv.2015.11.013 . hal-01251467

HAL Id: hal-01251467 https://hal-univ-rennes1.archives-ouvertes.fr/hal-01251467

Submitted on 6 Jan 2016

HAL is a multi-disciplinary open access archive for the deposit and dissemination of scientific research documents, whether they are published or not. The documents may come from teaching and research institutions in France or abroad, or from public or private research centers.
L'archive ouverte pluridisciplinaire HAL, est destinée au dépôt et à la diffusion de documents scientifiques de niveau recherche, publiés ou non, émanant des établissements d'enseignement et de recherche français ou étrangers, des laboratoires publics ou privés. 


\title{
HYGRIC AND THERMAL PROPERTIES OF HEMP-LIME PLASTERS.

\author{
Brahim MAZHOUD ${ }^{\text {a }}$, Florence COLLET ${ }^{\text {a }}$, Sylvie PRETOT ${ }^{\text {a }}$, Julien \\ CHAMOIN $^{\mathrm{a}}$
}

a Université de Rennes 1 - Laboratoire de Génie Civil et Génie Mécanique - Equipe Matériaux Thermo Rhéologie

postal address: IUT Génie Civil - 3, rue du Clos Courtel - BP 90422 - 35704 Rennes - France brahim.mazhoud@univ-rennes1.fr florence.collet@univ-rennes1.fr sylvie.pretot@univ-rennes1.fr julien.chamoin@hei.fr

* Corresponding author: Tel: 33.2.23.23.40.56, Fax: 33.2.23.23.40.51.

\begin{abstract}
Hemp-lime mortars are generally used as indoor insulating plasters of building envelopes. They can be applied in thick coat to allow high enough hygrothermal performances to be reached in retrofit case. This study investigates hygric and thermal properties of two hemp-lime plasters. These plasters are made with the same lime-based binder and differ from their kind of hemp shiv. The two kinds of hemp shiv are defibered but one is smaller than the other. This experimental study is based on the measurement of sorption isotherm, water vapour permeability, moisture buffer value and thermal properties (conductivity and diffusivity). The effect of temperature on moisture buffer value and on thermal properties is also investigated. It is shown that hemp-lime plasters are hygroscopic and breathable materials. They are good hygric regulators according to the Nordtest classification and their moisture buffering ability is slightly impacted by temperature in the range from $11^{\circ}$ to $23^{\circ} \mathrm{C}$. The hemp-lime plaster with the smallest hemp
\end{abstract}


shiv is a better hygric regulator than the one with the biggest hemp shiv. Hemp-lime plasters show a quite low thermal conductivity, around $0.2 \mathrm{~W} /(\mathrm{m} . \mathrm{K})$. The hemp-lime plaster with the smallest hemp shiv is slightly more conductive than the one with the biggest hemp shiv. The temperature does not impact thermal conductivity at dry state. At wet state, for a given relative humidity, when the temperature increases the thermal conductivity decreases simultaneously with water content. This study underlines that hemp-lime plasters show high hygrothermal qualities.

Keywords: bio-based material, sorption isotherm, water vapour permeability, moisture buffer value, penetration depth, thermal properties.

\section{Introduction}

In most constructions, walls are covered with plasters. These plasters, made of one or several layers, perform several functions. Firstly, plasters are used to homogenize wall surface. They can also be used to level or smooth a wall surface. The visual effect of plaster widely affects the overall look of the building. Thus, plasters have an aesthetic function. Plasters also have technical functions. The main technical function of external plasters is to protect walls from weather conditions, especially from rain and wind. External plaster are also involved in fire protection. In France, following the great Fire of London in 1666, a royal edict decreeded that external plasters had to be used as fireproofing material for halftimbered facades. Finally, new functions have been developed over the last decades: plasters may be used to increase thermal resistance of the walls, internal plasters are also used to moderate ambient relative humidity variation or to ensure high indoor air quality. Such aspects are useful in a context of sustainable development that requires safe and energy efficient buildings.

Traditionally, plasters were based on inorganic binder: lime, gypsum and, later, cement. Then, charges were added in order to improve one or several target properties. Finally, in a context of sustainable development, new products are also developed taking into account their environmental impact. Such plasters are made of low impacting materials, renewable raw or recycled material.

Thus, plasters used for building envelopes must meet requirements concerning their physico-chemical, mechanical, hygro-thermal and aesthetical qualities. It is shown that inadequate plaster, from a physico- 
chemical and from a mechanical point of view, can induce damage to the wall [1]. Their hygro-thermal characteristics should also keep the wall breathable. Actually, the negative effect of moisture on walls is well established and should be avoided. In order to select the most convenient plaster with a specific structural wall, Karoglou et al. [2] developed a simulator that allows to compare the effect of various kind of plasters and various thicknesses. The main moisture transfer mechanisms taken into consideration in this study are capillary suction and drying process.

For external plasters, in order to meet the requirements of historical building's conservator in term of composition and application methods, Vejmelkova et al. [3] developed plasters intended for application to renovation of historical building. They investigated several lime-pozzolana plasters made of the same lime and differing by the type of pozzolana admixture. The lime-pozzolana plasters show much higher mechanical performances than common lime-plaster. They also lead to lower water transport parameters while keeping slightly slower water vapour diffusion than in common lime-plaster. From a thermal point of view, the thermal conductivity of lime-pozzolana plasters is $12 \%$ lower than the thermal conductivity of pure lime plaster. Finally, the authors underlined that the finest pozzolana particles are the most successful solution.

Water in liquid state is also one of the main concerns in the development of external plasters. Actually, such water can induce several damages to the surface layer or to the structure of the wall due to freeze/thaw cycles or salt crystallization for example. Studies of hydrophobization of plasters are thus investigated in order to reduce the risk of liquid water in walls [4] [5].

For internal plasters, the main technical characteristics developed are their thermal and hygric performances and their ability to enhance indoor air quality.

In order to improve thermal performances of plasters, organic or inorganic light aggregates can be mixed in the formulation like cork, vermiculite or perlite, silica pearls of expanded polystyrene, bio-based aggregate, recycled material... [6] [7] [8]. Bianco et al. [9] showed the performance of thermal insulating plaster made from natural hydraulic lime of Wasselonne and vegetal aggregate materials derived from the waste of the corn production. Their study was performed on real buildings where this plaster is sprayed 
on walls. It is shown to be a good solution for historical building retrofit, leading to a reduction in energy losses of about 20 to $40 \%$.

From a hygric point of view, the use of hygroscopic plasters both regulate indoor humidity and improve ambient comfort conditions. Among hygroscopic plasters, clay-based plasters are good hygric regulators. Zhang and al. [10] underlined that clay-based plasters reduce the risk of surface condensation and improve the occupant's health and the durability of the building by reducing humidity fluctuations. This good performance can be improved by adding charge in the matrix. Maddison et al. [11] showed that the use of natural fibres issued from common plants used for wastewater treatment in clay-sand plasters accelerates and increases moisture absorption in the material.

Finally, internal plasters impact indoor air quality. Darling et al. underlined that clay plasters also allows improving perceived air quality [12].

Among environmentally-friendly raw materials, hemp shiv have many advantages as they are bio-based materials (renewal, recycling, carbon sequestration...). Their use was developed within the last two decades as they allow to reduce density and thus decrease thermal conductivity. It was shown that the thermal conductivity of hemp concrete is quite low (about $0.1 \mathrm{~W} /(\mathrm{m} . \mathrm{K})$ while these materials show a high hygroscopic behaviour due to the coupling of hemp shiv and binder [13] [14] [15] [16] [17] [18] [19] [20].The production of hemp shiv provides several sizes of aggregates. The smallest hemp shiv are also used to produce hemp-lime plasters with aesthetical aspect and good hygrothermal behaviour.

This study investigates two hemp-lime plasters used for building. These materials differ in their type of hemp shiv: one of them is made of Chanvribat defibered hemp shiv (CHLP) and the other one is made of Terrachanvre F defibered hemp shiv (THLP). Such plasters are used on indoor side as thermal and hygric regulator. The aim of this study is to assess their hygrothermal performances. The characterization is based on the measurement of thermal conductivity, thermal diffusivity and moisture buffer value. The effect of temperature on these properties is also investigated as building envelopes are exposed to the variation of indoor and outdoor temperature (climate, vacancy period...). This may impact the thermal properties and the moisture buffering ability of materials. It is thus crucial to quantify the variation of these properties with temperature. 


\section{Methods and materials}

\subsection{Sorption isotherm at $23^{\circ} \mathrm{C}$}

The sorption isotherm relates the amount of equilibrium moisture content to the ambient relative humidity for a given temperature.

Sorption isotherms can be measured according to continuous or discontinuous methods [21]. The continuous method consists in measuring the sorption curve under quasi-equilibrium conditions. The adsorptive is admitted (or removed) at a slow and constant rate. The variation of the amount adsorbed by the specimen, with increase (or decrease) in pressure is measured by the volumetric or gravimetric method. The discontinuous method consists in measuring the amount adsorbed by the specimen at successive stages of increasing (and then decreasing) pressure. It can be performed with desiccators and saturated salt-solutions, with climatic chambers or with DVS (dynamic vapour sorption) that has been developed to reduce the running time of measurement but can be used with small specimens only.

In this study, the sorption isotherms are measured according to the discontinuous method: the moisture content is determined at successive stages of increasing (and then decreasing) relative humidity. The specimens are placed in a climate chamber (Vötsch VC4060) which regulates temperature and relative humidity. The specimens are weighed two to three times a week. The sorption isotherm is measured at 23 $\pm 0.1^{\circ} \mathrm{C}$ as requested by NF EN ISO 12571 standard. Relative humidity rates used for this study are 11, 23, 33, 43, 58, 81, 90, 95 and $97 \% \mathrm{RH}$. The water content $w$ is calculated from the mass of the specimen with Eq. (1).

$$
w=\frac{m-m_{0}}{m_{0}}
$$

where $m$ is the mass of the sample in steady state conditions $(\mathrm{kg})$ and $m_{0}$ is the mass of the sample in the initial dry state $(\mathrm{kg})$. 
In order to reduce the time of exposure (to reduce the running time of measurement and to avoid moulds growing), the kinetic of water content is modelled [16]. This allows to measure the whole adsorptiondesorption curve within 1.5 year.

Several models have been developed to describe the sorption curve [22][23]. Guggenheim [24], Anderson [25, 26] and De Boer [27] have developed the GAB model (2). This model relates the water content to the specific surface area of the material for multilayer sorption. Even if this model is physically valid when there is no capillary condensation; the GAB model covers a wide range of relative humidity (0.05 to 0.80.9 ) and is convenient to fit experimental adsorption data all over the RH range.

$$
\frac{w}{w_{m}}=\frac{C_{G} \cdot k \cdot \varphi}{(1-k \cdot \varphi)\left(1-k \cdot \varphi+C_{G} \cdot k \cdot \varphi\right)}
$$

Where $w_{m}$ is the monomolecular water content $(\mathrm{kg} / \mathrm{kg}), C_{G}$ and $k$ are the fitting parameters of the GAB model, and $\varphi$ is the relative humidity (-).

\subsection{Water vapour permeability}

The water vapour permeability characterises the ability of a material to transfer moisture under a vapour pressure gradient once the steady state is reached. The commonly called "vapour permeability" includes (i) vapour transfer by diffusion (transport by collision of water molecules with each other), (ii) vapour transfer by effusion (transport by collision of water molecules with walls of pores) and (iii) liquid transfer (connected with capillary condensation).

As recommended by NF EN ISO 12572 standard, the water vapour permeability is measured under isothermal conditions (at $\left.23^{\circ} \mathrm{C}\right)$. Firstly, the dry cup test of this standard $(0 / 50 \% \mathrm{RH})$ is performed. Then, in order to access the variation of water vapour permeability with relative humidity, , several pairs of relative humidity are investigated: (0/23), (23/43),(43/58), (58/81), (81/90) and (81/94). These measurements were performed in adsorption. Previously to the dry cup test, the specimens were dried and 
then tests were carried out from lowest RH to highest RH. Prior to each test, the specimens were stabilised to the lowest RH of the test.

The specimen is embedded at the top of the cup. The relative humidity in the cup, $\varphi_{\text {int }}$, is controlled by saturated salt solutions or silica gel while the relative humidity around the cup, $\varphi_{\text {ext }}$, is controlled by air conditioning. The difference of water vapour pressures leads to a flux. The device is weighed periodically and when the gain in mass is constant, the mass change rate $G$ is calculated by linear regression between mass and time and the water vapour permeability $\pi$ is then deduced:

$$
\begin{gathered}
G=\frac{\Delta m}{\Delta t} \\
\pi=\frac{G \cdot e}{A \cdot\left(\Delta p_{v}\right)}
\end{gathered}
$$

Where $G$ is the mass change rate $(\mathrm{kg} / \mathrm{s}), \Delta m$ is the mass variation $(\mathrm{kg})$ and $\Delta t$ is the time (s),

And $\pi$ is the water vapour permeability ( $\mathrm{kg} /(\mathrm{m} . \mathrm{s} . P a))$, e is the thickness of the specimen (m), $\mathrm{A}$ is the exposed surface area $\left(\mathrm{m}^{2}\right)$ and $\Delta p_{v}$ is the vapour pressure difference $(\mathrm{Pa})$.

The vapour pressure is calculated from temperature and relative humidity measured during test period with the usual relationship:

$$
p_{v}=\varphi \cdot 100 \exp \left(18.986-\frac{4052}{235.89+\theta}\right)
$$

Where $p_{v}$ is the vapour pressure (Pa), $\varphi$ is the relative humidity (-) and $\theta$ is the temperature $\left({ }^{\circ} \mathrm{C}\right.$ ).

The experimental data on water vapour permeability versus relative humidity are fitted with a power law relationship according to (6): 


$$
\pi=A+B \cdot \varphi^{C}
$$

Where $\pi$ is the water vapour permeability (kg/(m.s.Pa)) and A, B and C are the fitting coefficients with A and B (kg/(m.s.Pa)).

\subsection{Moisture buffer value}

The dynamic moisture storage and release in hygroscopic building materials is linked to the moisture exchange on the surface area of the material and to the moisture flow in the material.

The practical moisture buffer value MBV quantifies the moisture buffering ability of a material, measured under dynamic conditions. It is measured according to the method defined in the NORDTEST project [28]. This value relates the amount of moisture uptake (and release), per open surface area, under daily cyclic variation of relative humidity according to equation (7). This value is mainly but not only a property of the material as the mass transfer coefficient at the boundary plays a role. Though, for many materials, the internal resistance to moisture transport is significantly larger than the convective surface resistance.

$$
M B V=\frac{\Delta m}{A .\left(R H_{\text {high }}-R H_{\text {low }}\right)}
$$

Where $M B V$ is the Moisture Buffer Value $\left(\mathrm{kg} /\left(\mathrm{m}^{2} . \% \mathrm{RH}\right)\right), \Delta m$ is the moisture uptake / release during the period (kg), $A$ is the open surface area $\left(\mathrm{m}^{2}\right)$ and $R H_{\text {high /low }}$ are the high/low relative humidity level (\%).

Within the NORDTEST project, a round robin test was performed on nine representative building materials. It gives initial results and leads to a classification of moisture buffer values from negligible to excellent (Fig. 1). 


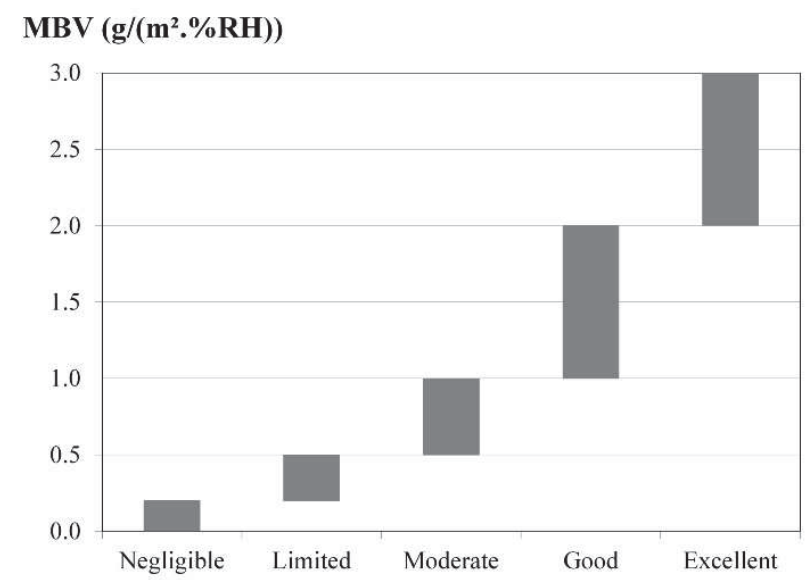

Fig. 1. Ranges for practical moisture buffer value classes [28]

The test method requires prismatic specimens to be sealed on five out of six sides. After stabilization at $\left(23^{\circ} \mathrm{C} ; 50 \% \mathrm{RH}\right)$, specimens are exposed to daily cyclic variations: 8 hours at high relative humidity (75\%) followed by 16 hours at low relative humidity (33\%). This time scheme replicates the daily cycle seen in many rooms (eg offices, bedrooms...) where the load comes in approximately 8 hours. The test goes on until the change in mass $\Delta \mathrm{m}$ is the same between the last three cycles with less than $5 \%$ of discrepancies. For each specimen, the MBV is thus the average value calculated from the last 3 cycles. The MBV of the material is thus the average value of the three specimens.

The device used for MBV test is a climate chamber Vötsch VC4060 with a temperature range from +10 to $+95^{\circ} \mathrm{C}$ and a relative humidity range from 10 to $98 \% \mathrm{RH}$. The relative humidity is switched manually according to the (8 hours at $75 \%$ RH; 16 hours at 33\%RH) scheme. Temperature and relative humidity are measured continuously with Sensirion SHT75 sensors and with the sensor of the climate chamber. The air velocity is measured in the surroundings of the specimens: the vertical velocity is in the range 0.07 to $0.14 \mathrm{~m} / \mathrm{s}$ and the horizontal one is 0.1 to $0.4 \mathrm{~m} / \mathrm{s}$ like in a normal indoor environment. The specimens are weighed out of the climate chamber five times during the absorption period and two times during the desorption period. The weighing instrument reading is $0.01 \mathrm{~g}$, and its linearity is $0.01 \mathrm{~g}$. The accuracy of the moisture buffer value is thus about $5 \%$.

The effect of temperature on the moisture buffering ability of hemp-lime plasters is investigated considering a temperature range representative of temperatures met in buildings. The test is thus 
performed at $23^{\circ} \mathrm{C}$ (following the Nordtest protocol) and at $20,17,14$ and $11^{\circ} \mathrm{C}$, from the highest to the lowest temperature. For a given relative humidity, a lower temperature induces a lower water vapour pressure. The moisture flux over the surface of the material being proportional to the water vapour pressure gradient, the effect of temperature on moisture buffering ability is also investigated considering a corrected moisture buffer value MBV', defined versus water vapour pressure as given by equation (8):

$$
M B V^{\prime}=\frac{\Delta m}{A \cdot\left(P_{\text {vhigh }}-P_{\text {vlow }}\right)}
$$

\subsection{Penetration depth}

ARFVIDSSON [29] defines the moisture penetration depth as the depth where the amplitude of moisture content variation is only $1 \%$ of the variation on the material surface. For sinusoidal variation of moisture content on the material surface, the penetration depth is given by equation (9):

$$
d_{p, 1 \%}=4.61 \sqrt{\frac{D_{m} \cdot t_{p}}{\pi}}
$$

Where $d_{(p, 1 \%)}$ is the penetration depth $(m), D_{m}$ is the moisture diffusivity of the material $\left(\mathrm{m}^{2} / \mathrm{s}\right)$ and $t_{p}$ is the time period (s).

In the NORDTEST protocol, the relative humidity at the boundary of material follows a square wave, not a sinusoidal one. So, this method for calculation of penetration depth gives only an approximation.

The moisture diffusivity is calculated from sorption curve and water vapour permeability with [30]:

$$
D_{u}=\frac{\pi \cdot P_{v s}}{\rho_{0}} \cdot \frac{1}{\frac{\partial w}{\partial \varphi}}
$$


Where $D_{u}$ is the water vapour diffusivity $\left(\mathrm{m}^{2} / \mathrm{s}\right), \pi$ is the water vapour permeability $(\mathrm{kg} /(\mathrm{m} . \mathrm{s} . P a)), P_{v s}$ is the vapour pressure at saturation $(\mathrm{Pa}), \rho_{0}$ is the dry density $\left(\mathrm{kg} / \mathrm{m}^{3}\right), \frac{\partial w}{\partial \varphi}$ is the derivative of the sorption curve.

\subsection{Thermal properties}

The thermal properties investigated are the thermal conductivity and the thermal diffusivity. The thermal conductivity is the ability of a material to conduct heat under temperature gradient and steady state conditions. It quantifies how much heat flows in a material. The thermal diffusivity describes the rate at which heat flows through a material, characterizing unsteady heat conduction. It quantifies how rapidly heat flows within it.

The measurements are performed with transient state methods: hot wire which provides thermal conductivity and hot disk which provides both thermal conductivity and diffusivity. The main advantage of these methods, compared to steady-state methods like hot plate, is that transient methods do not induce (or limit) water migration during test [31]. Thus, they allow measurements at wet state. For both methods, the sensor is sandwiched between two specimens. The contact surface of specimens is as flat as possible in order to ensure the thinner air layer between specimens. For the two materials, two pairs are realized from three specimens. As these methods lead to localised measurements, tests are repeated several times at several places to ensure the representativeness of the thermal properties values.

The Hot Disk is based on the transient plane source (TPS) theory to measure thermal conductivity and thermal diffusivity. The commercial TPS 1500 device allows to measure thermal conductivity in the range from 0.01 to $400 \mathrm{~W} /(\mathrm{m} . \mathrm{K})$ and thermal diffusivity in the range from 0.1 to $100 \mathrm{~mm}^{2} / \mathrm{s}$. The Hot disk manufacturer quotes accuracies better than $5 \%$ for the instrument. The TPS sensor used in the present study is Ref.4922. The outer radius of the double-spiral heater is $14.61 \mathrm{~mm}$. The heat flow and heating time are chosen to reach high enough temperature rise $\left(0.4\right.$ to $2.6^{\circ} \mathrm{C}$ as recommended by the manufacturer), probing depth lower than the available probing depth $(2.5 \mathrm{~cm})$ and total characteristic time between 0.33 and 1 . The Mean deviation around the fitted line must be lower than $0.001 \mathrm{~K}$. The heating power is $50 \mathrm{~mW}$ for CHLP and $55 \mathrm{~mW}$ for THLP. The heating time is $640 \mathrm{~s}$ for both plasters. The 
thermal properties of a pair of specimens are the average of the three values with a variation coefficient lower than 5\%. The thermal properties of one material are the average values of its two pairs.

The measurement of thermal conductivity with hot wire is based on the analysis of the temperature rise versus heating time. The heat flow and heating time are chosen to reach high enough temperature rise $\left(>10^{\circ} \mathrm{C}\right)$ and high correlation coefficient $\left(\mathrm{R}^{2}\right)$ between experimental data and fitting curve. In this study, the power used is $0.23 \mathrm{~W}$ for the two plasters and the heating time is $130 \mathrm{~s}$ for the CHLP and $120 \mathrm{~s}$ for THLP. The thermal conductivity of a pair of specimens is the average of five values with a variation coefficient lower than 5\%. The thermal conductivity of one material is the average value of its two pairs.

\subsection{Materials and specimens}

This study investigates two kinds of hemp-lime plasters which differ from their type of hemp shiv (Fig. 2, Tab. 1). These plasters are generally used internally but occasionally they can be used externally with a finishing coat. These indoor plasters are used as thermal correctors and also play a role as hygric regulators. They can be built up to substantial thicknesses (about 4 to $8 \mathrm{~cm}$ ) to achieve significant hygrothermal qualities.
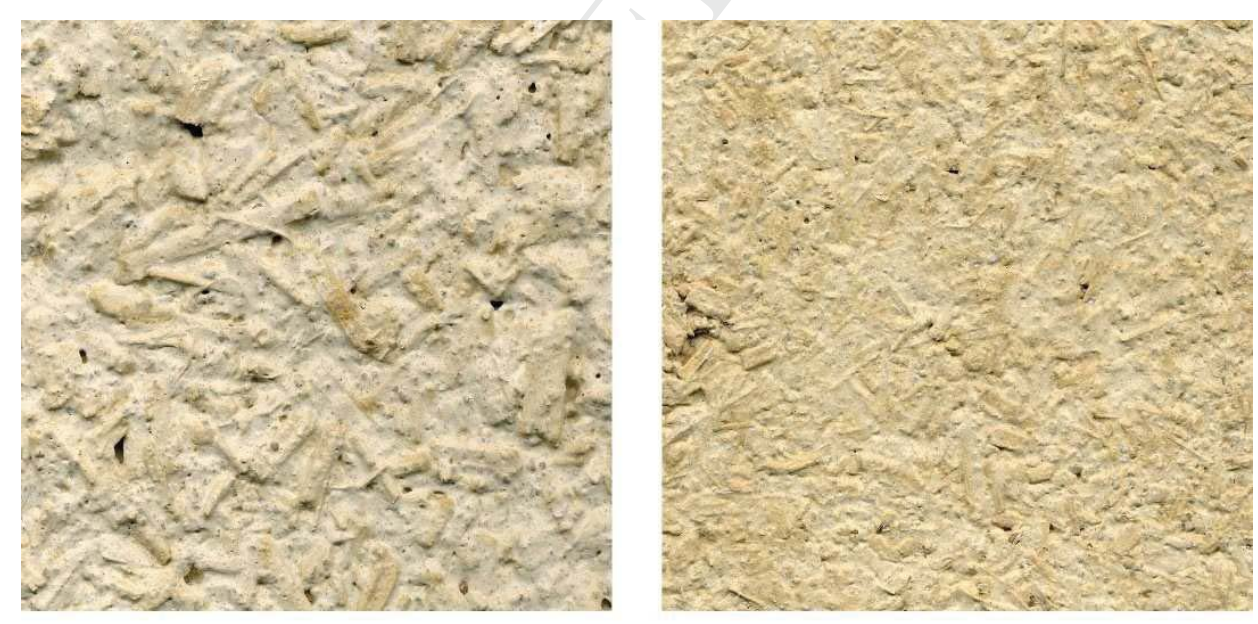

$1 \mathrm{~cm}$

Fig. 2: Picture of specimens: Chanvribat hemp-lime plaster (left) and Terrachanvre hemp-lime plaster (right). 
The lime-based binder used is a commercial product (Tradichanvre BCB - BCB France) commonly used to produce hemp-lime plasters. This binder is made of 35\% of mineral additions and $65 \%$ of lime based binder composed of air-slake lime (85\%) and hydraulic lime (15\%).

The shiv used are commercial products Chanvribat (from LCDA France) and Terrachanvre F (from Terrachanvre France). Their bulk density is about 100 to $110 \mathrm{~kg} / \mathrm{m}^{3}$. Their particle size distribution, measured by sieving, are given in figure 3. The mean width of shiv (D50) is $3.2 \mathrm{~mm}$ for Chanvribat and $1.7 \mathrm{~mm}$ for Terrachanvre F. The width/length ratio is about 4 for the two kinds of shiv. Terrachanvre F shiv is thus smaller than Chanvribat shiv.

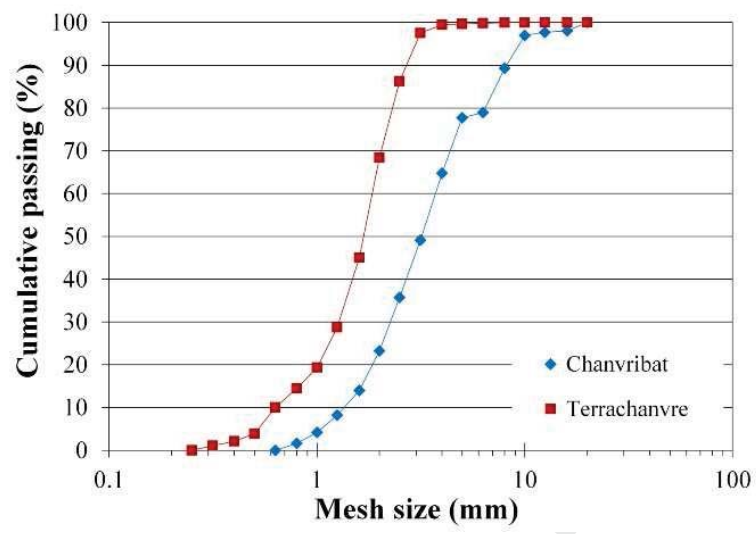

Fig. 3. Particle Size Distribution of Chanvribat and Terrachanvre F shiv

For this study, hemp-lime plaster blocks are produced by moulding. First, hemp shiv and lime-based binder Tradichanvre are mixed with a hemp to binder mass ratio of 0.15 . The mixing water is adjusted to obtain a consistent workability of fresh hemp-lime plaster with a satisfactory rheology. Moulds are filled with the mixture and the hemp-lime plaster is slightly compacted. The density of hemp-lime plasters is about $715-730 \mathrm{~kg} / \mathrm{m}^{3}$ for CHLP and $865-895 \mathrm{~kg} / \mathrm{m}^{3}$ for THLP. Their porosity is high (72 and $66 \%$ respectively) and mainly open, nearly exclusively for THLP (Tab. 2). More CHLP shows larger macropores than THLP, visible to the naked eye (Fig. 2). 
Tab. 1: Composition of the studied hemp-lime plasters

\begin{tabular}{ccccc}
\hline Material & Notation & Binder & Hemp shiv & $\begin{array}{c}\text { Hemp/binder mass } \\
\text { ratio }\end{array}$ \\
\hline $\begin{array}{c}\text { Chanvribat } \\
\text { hemp-lime plaster } \\
\begin{array}{c}\text { Terrachanvre } \\
\text { hemp-lime plaster }\end{array}\end{array}$ & CHLP & $\begin{array}{c}\text { Tradichanvre } \\
\text { lime based binder } \\
\text { Tradichanvre }\end{array}$ & $\begin{array}{c}\text { Chanvribat } \\
\text { defibered hemp shiv } \\
\text { Terrachanvre F } \\
\text { lime based binder }\end{array}$ & 0.15 \\
\hline
\end{tabular}

Tab. 2: Physical properties of the studied hemp-lime plasters

\begin{tabular}{cccc}
\hline & $\begin{array}{c}\text { Density } \\
\left(\mathrm{kg} / \mathrm{m}^{3}\right)\end{array}$ & $\begin{array}{c}\text { Total } \\
\text { porosity } \\
(\%)\end{array}$ & $\begin{array}{c}\text { Open } \\
\text { porosity } \\
(\%)\end{array}$ \\
\hline CHLP & $723 \pm 8.8$ & 72 & 65.5 \\
THLP & $881 \pm 16.5$ & 65.9 & 64.2 \\
\hline
\end{tabular}

For hygric and thermal studies, specimens are cut from blocks with a band saw or with a core drill and are selected to be representative of the material (density and homogeneity). Their sizes include the elementary representative volume (ERV) which is the smallest volume over which a measurement can be made to yield a value representative of the whole [32]. Smaller volumes are impacted by microscopic heterogeneity while highest volumes are impacted by macroscopic heterogeneity. Specimens used to measure sorption curve are cylinders $5 \mathrm{~cm}$ in diameter and $7 \mathrm{~cm}$ high. Specimen used to measure water vapour permeability are cylinders $11 \mathrm{~cm}$ in diameter and $5 \mathrm{~cm}$ high. Specimens used to measure moisture buffer value and thermal properties are $15 \times 15 \times 8 \mathrm{~cm}^{3}$ blocks. Their sizes are chosen to meet the requirements of the NORDTEST project. The thicknesses are higher than the penetration depth during the test (section 3) and the total exposed surface area is higher than $300 \mathrm{~cm}^{2}$ for each material (adding the three specimens) [28].

\section{Hygric and thermal properties at $23^{\circ} \mathrm{C}$}

\subsection{Sorption isotherms}

Hemp-lime plasters are hygroscopic materials. Figure 4 gives the sorption isotherms of the two studied hemp-lime plasters and table 3 gives the GAB model parameters. These curves are sigmoid and are 
classified as type II or III according to the IUPAC's classification [21]. This is consistent with the fact that these classes are given for macroscopic media. Moreover, these sorption curves show hysteresis which extends to the lowest pressures.

These sorption curves are close to each other. Their water contents are similar for adsorption and for desorption branches, leading to similar hysteresis. For low and middle relative humidity, the gravimetric water content increases slightly versus relative humidity to reach about 1 to $1.2 \%$ (resp. THLP, CHLP) at 58\% RH for the adsorption curve. For higher relative humidity, the capillary condensation arises, the water content strongly increases to reach about $10 \%$ at $97 \%$ RH. Adsorption and desorption curves are nearly parallel over a wide range of relative humidity. The hysteresis ranges from $1.4 \%$ to $2.7 \%$, with highest values around $81 \% \mathrm{RH}$. This phenomenon commonly explained by the capillary condensation hysteresis, the contact angle hysteresis and the ink-bottle effect [33] is also due to irreversible uptake of molecules in pores (or through pore entrances) of the same width as that of the adsorbate, or to irreversible chemical interaction of the adsorbate with the adsorbent [21]. A part of the residual mass may also be due to the start of lime carbonation that probably occurred during the tests at high relative humidity. Finally, since the two hemp-lime plasters are made with the same binder and the same hemp to binder ratio, it seems that these two parameters are those which determine the sorption curve of hemplime plasters. The kind of hemp shiv has a low impact on sorption curve in this study.

Tab. 3. Sorption curves: Fitting parameters of the GAB model for the two hemp-lime plasters

\begin{tabular}{cccc}
\hline & $w_{m}(\mathrm{~kg} / \mathrm{kg})$ & $C_{G}$ & $k$ \\
\hline CHLP & 0.00455 & 10.45 & 0.9854 \\
THLP & 0.00368 & 21.40 & 0.9925 \\
\hline
\end{tabular}



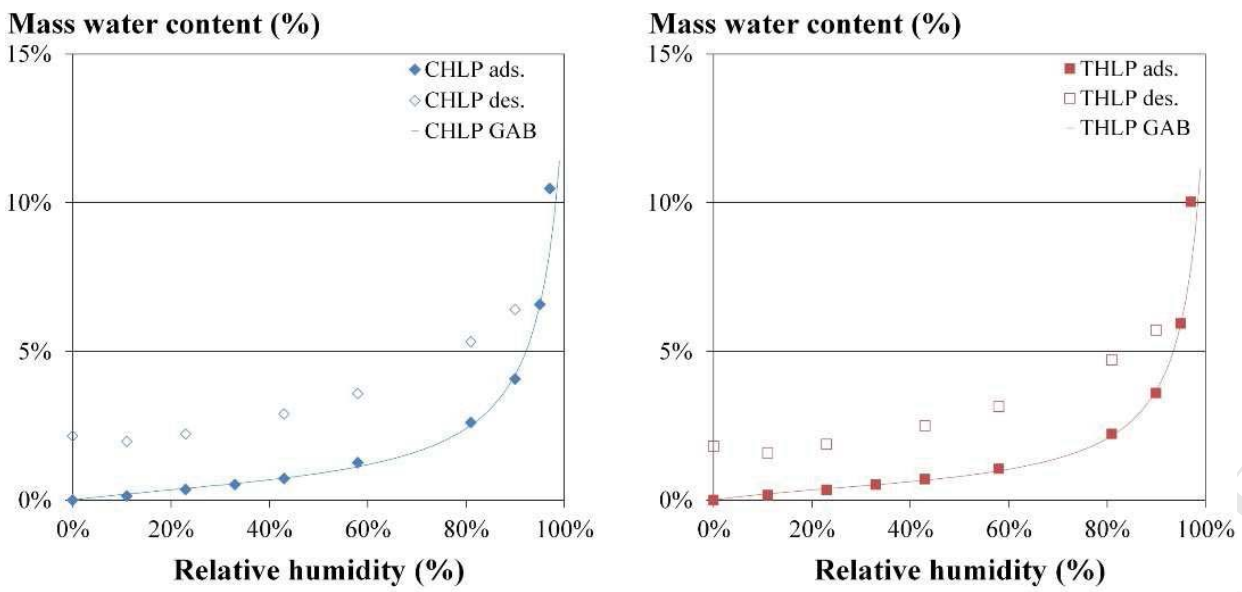

Fig. 4. Sorption curves (mass water content) of Chanvribat hemp-lime plaster (left) and Terrachanvre hemp-lime plaster (right)

Compared to hemp concrete, hemp-lime plasters show lower mass water content than hemp concretes given in [16]. However, when expressed as volume water content, the values are similar for hemp-lime plasters as for hemp concrete (with volume water content value about $0.9 \%$ at 58\% RH) (Fig. 5). For a given volume, the storage capacities of hemp-lime plasters are thus similar as those of hemp concretes.
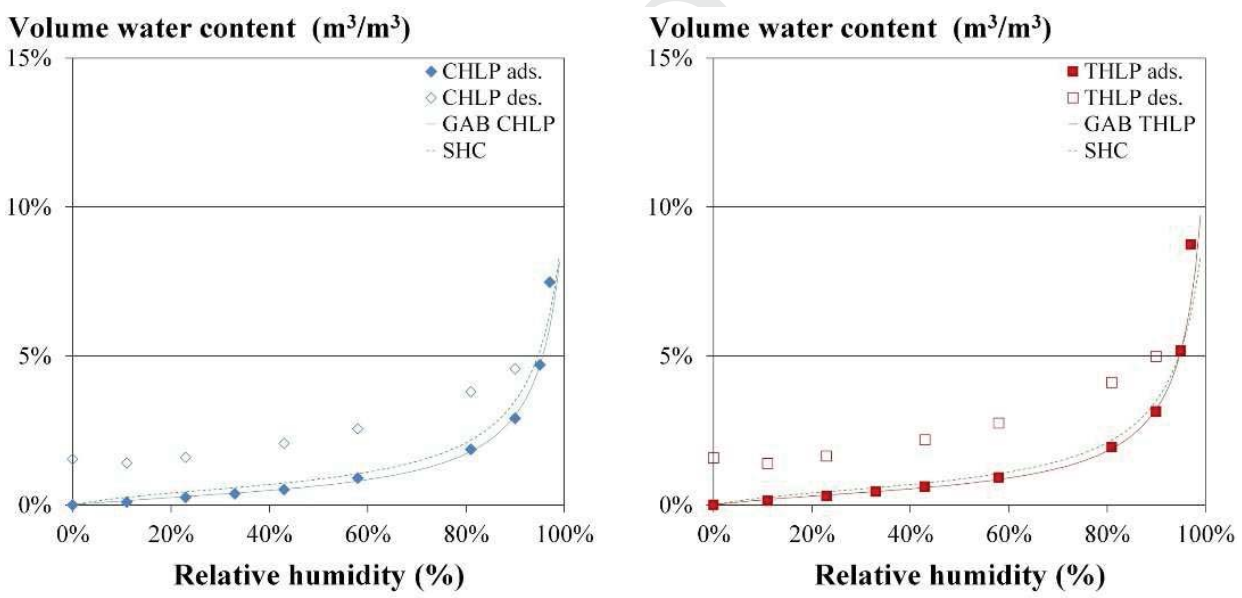

Fig. 5. Sorption curves (volume water content) of Chanvribat hemp-lime plaster (CHLP) and

Terrachanvre hemp-lime plaster (THLP), compared to sorption curve of Sprayed Hemp Concrete SHC (calculated from [16])

\subsection{Water vapour permeability}


Figure 6 gives the variation of moisture permeability versus ambient relative humidity for the two hemplime plasters. The parameters of the fitting power law (Eq.(6)) are given in table 4.

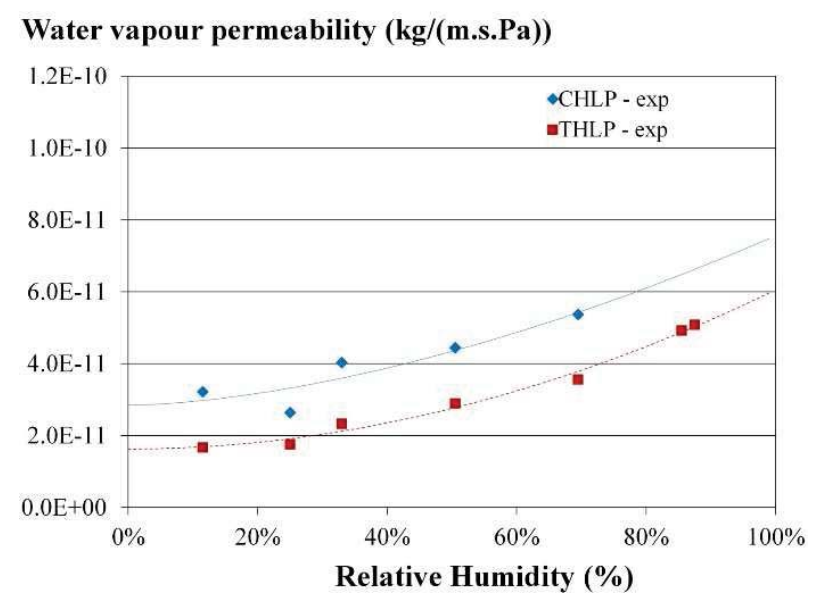

Fig 6. Water vapour permeability versus Relative Humidity of the two hemp-lime plasters.

Tab. 4. Variation of water vapour permeability versus relative humidity: parameters of the fitting powerlaw relationship (Eq.(6)) for the two hemp-lime plasters.

\begin{tabular}{cccc}
\hline & A & B & C \\
\hline CHLP & $2.85 \mathrm{E}-11$ & $4.71 \mathrm{E}-11$ & 1.655 \\
THLP & $1.63 \mathrm{E}-11$ & $4.43 \mathrm{E}-11$ & 1.971 \\
\hline
\end{tabular}

The mainly open high porosity of hemp-lime plasters gives them high water vapour permeability. The moisture permeability value is lower for THLP than for CHLP. For the two hemp-lime plasters, the water vapour permeability gradually increases over the whole range of relative humidity. These values respectively range from 1.6 E-11 to 5 E-11 and from 2.8 E-11 to 6.5 E-11 kg/(m.s.Pa). Actually, for hygroscopic materials, the water vapour permeability increases with the water content of the material as moisture transfer mode changes with water content (from vapour transfer to liquid transfer). The Terrachanvre shiv being smaller than the Chanvribat shiv, the size of channel in shiv is lower. This induces higher resistance to moisture flow in the material.

\subsection{Moisture buffer value}


The steady state is reached from the third cycle: the change in mass $\Delta \mathrm{m}$ and the moisture buffer value vary less than $5 \%$ within each cycle. Table 5 gives the average value of the MBV calculated from cycles 3 to 5 in adsorption, desorption and average for the two hemp-lime plasters. The value is very slightly higher in desorption than in adsorption. Actually, after stabilization at $23^{\circ} \mathrm{C} ; 50 \% \mathrm{RH}$, the test begins under adsorption at $75 \% \mathrm{RH}$. These conditions are higher than the average of the quasi steady state conditions which arise after some cycles. There is thus a declining tendency in the variation of mass which induces higher value in desorption than in adsorption. These two values are approaching each other after repeated cycles.

Tab. 5. Moisture Buffer Value in adsorption, desorption and average for the two hemp-lime plasters

\begin{tabular}{cccc}
\hline & $\begin{array}{c}\text { MBV ads. } \\
\left(\mathrm{g} /\left(\mathrm{m}^{2} . \% \mathrm{RH}\right)\right)\end{array}$ & $\begin{array}{c}\text { MBV des. } \\
\left(\mathrm{g} /\left(\mathrm{m}^{2} . \% \mathrm{RH}\right)\right)\end{array}$ & $\begin{array}{c}\text { MBV av. } \\
\left(\mathrm{g} /\left(\mathrm{m}^{2} . \% \mathrm{RH}\right)\right.\end{array}$ \\
\hline CHLP & 1.18 & 1.27 & 1.23 \\
THLP & 1.59 & 1.68 & 1.64 \\
\hline
\end{tabular}

The MBV of the CHLP and of the THLP are respectively: 1.23 and $\left.1.64 \mathrm{~g} /\left(\mathrm{m}^{2} . \% \mathrm{RH}\right)\right)$. According to the classification of the NORDTEST Project, these materials are good hygric regulators $\left(1<\mathrm{MBV}<2 \mathrm{~g} /\left(\mathrm{m}^{2}\right.\right.$ \%RH)). The THLP is better hygric regulator than CHLP. The moisture transfer being more efficient in CHLP (water vapour permeability and diffusivity), the higher MBV value of THLP is probably due to higher storage in link with hysteretic behaviour.

The moisture buffer value obtained for the two hemp-plasters is lower than value met in literature for hemp concrete: about $1.99 \mathrm{~g} /\left(\mathrm{m}^{2} \% \mathrm{RH}\right)$ [34] to $2.15 \mathrm{~g} /\left(\mathrm{m}^{2} \% \mathrm{RH}\right)$ [16]. This is due to the lower hemp to binder ratio in hemp-lime plaster than in hemp concrete. This induces higher density and lower permeability in hemp-lime plasters.

The MBV of hemp-lime plasters make them better hygric regulators than other materials used for plastering like gypsum (MBV about $0.6 \mathrm{~g} /\left(\mathrm{m}^{2} . \% \mathrm{RH}\right)$ ) [28]. However, to ensure this hygric capacity a high enough thickness must be used, higher than the penetration depth.

\subsection{Penetration depth}


The moisture penetration depth calculated from equation (9) and using the values of relative humidity recorded during the MBV test are $6.8 \mathrm{~cm}$ for CHLP and $5.5 \mathrm{~cm}$ for THLP. The penetration depth is higher for CHLP, in link with higher value of hygric diffusivity. Even if these values of penetration depth are an approximation, they allow us to validate the results presented here as they are lower than the thickness of the specimens. More, although these quantitative results should be viewed as indications of the order of magnitude only, they point the required thickness to fully benefit from the moisture buffering capacity of hemp-lime plasters. If the thickness is lower, the moisture buffering capacity of the wall also depends on the type of background which is plastered.

\subsection{Thermal properties}

For all the measurements performed with the hot wire, the correlation coefficient between experimental data and fitting curve is very close to 1 ( higher than 0.996).

Table 6 shows the mean values, standard deviations and coefficients of variation of thermal conductivity and thermal diffusivity measured with hot wire and hot disk at $\left(23^{\circ} \mathrm{C}, 50 \% \mathrm{RH}\right)$. Each value is the average of 10 measures with hot wire (5 per pair) and 6 measures with hot disk (3 per pair).

For the two hemp-lime plasters, the coefficient of variation between experimental data is lower than $4 \%$ as well for thermal conductivity as for thermal diffusivity. The results obtained with Hot Disk are lower than those obtained with Hot Wire (less 10\%). This discrepancy is acceptable as the precision of each experimental device is $5 \%$.

The thermal conductivity of the CHLP is lower than that of THLP (0.180 and $0.214 \mathrm{~W} /(\mathrm{m} . \mathrm{K})$ respectively). This was expected as CHLP has lower density and higher porosity than THLP (Tab. 2). Moreover, the size of porosity induced by hemp shiv may also play a role.

These results are similar to the values given by Pretot [35], where the thermal conductivity of hemp-lime plasters is $0.193 \mathrm{~W} /(\mathrm{m} \cdot \mathrm{K})$ at $692 \mathrm{~kg} / \mathrm{m}^{3}$ and $0.227 \mathrm{~W} /(\mathrm{m} . \mathrm{K})$ at $808 \mathrm{~kg} / \mathrm{m}^{3}$.

Thanks to hemp shiv, the two hemp-lime plasters have lower thermal conductivity than usual plasters. Actually, it is found in literature that, at dry state, the thermal conductivity of lime-metakaolin plasters 
ranges from 0.650 to $0.726 \mathrm{~W} /(\mathrm{m} . \mathrm{K})$ with density about $1750 \mathrm{~kg} / \mathrm{m}^{3}$ [36]. Hydrophobisation allows to increase porosity, and thus, reduce thermal conductivity of lime-metakaolin plasters to 0.413 to 0.499 W/(m.K) (with density of 1450 and $1580 \mathrm{~kg} / \mathrm{m}^{3}$ ) [4]. Lastly, the thermal conductivity of commercial renovation plasters studied by Vejmelkova [4] ranges from 0.293 to $0.366 \mathrm{~W} /(\mathrm{m} . \mathrm{K})$ with respective density of 1296 and $1384 \mathrm{~kg} / \mathrm{m}^{3}$.

Compared with other hemp-based building material, studied hemp-lime plasters show higher thermal conductivity than the values obtained from the relationship established by Cerezo for hemp concrete [15]. Actually, equation (11) gives a thermal conductivity of $0.166 \mathrm{~W} /(\mathrm{m} . \mathrm{K})$ when the density is $733 \mathrm{~kg} / \mathrm{m}^{3}$. This is due to lower hemp to binder ratio in the case of hemp-lime plaster.

$$
\lambda=0.0005 \times \rho+0.0194
$$

Finally, compared with other bio-based materials used as extra thermal insulation, studied hemp-lime plasters have lower thermal conductivity than wood-polystyren composite studied by Agoua $(\lambda=0.274$ $\left.\mathrm{W} /(\mathrm{m} . \mathrm{K}) ; \rho=664 \mathrm{~kg} / \mathrm{m}^{3}\right)$ [37], than clay-cement-wood composite studied by Al-Rim $(\lambda=0.22 \mathrm{~W} /(\mathrm{m} . \mathrm{K})$; $\left.\rho=1010 \mathrm{~kg} / \mathrm{m}^{3}\right)$ [38] and than wood concrete in [39] $\left(\lambda=0.25 \mathrm{~W} /(\mathrm{m} . \mathrm{K}) ; \rho=1495 \mathrm{~kg} / \mathrm{m}^{3}\right)$.

The thermal diffusivities measured on the two hemp-lime plasters are similar: $0.25 \mathrm{~mm}^{2} / \mathrm{s}$ for CHLP and $0.23 \mathrm{~mm}^{2} / \mathrm{s}$ for THLP. They are in the range of thermal diffusivity given by Taoukil for wood concrete [39]. The specific heat capacity calculated from thermal conductivity and thermal diffusivity are thus 996 J/(Kg.K) for CHLP and 1009 J/(Kg.K) for THLP. These values are also close to the values found by Vejmelkova on lime-metakaolin plasters (911 to $988 \mathrm{~J} /(\mathrm{Kg} . \mathrm{K})$ with density about $1750 \mathrm{~kg} / \mathrm{m}^{3}$ )[4]. Actually, the specific heat capacity of building material usually ranges from 800 to $2000 \mathrm{~J} /(\mathrm{kg} . \mathrm{K})$ (as given in the database of the France’s RT 2012 energy regulation).

Tab. 6: Thermal properties of materials at $23^{\circ} \mathrm{C}, 50 \% \mathrm{RH}$

Hot Wire

\begin{tabular}{|c|cc|ccc}
\hline & $\lambda$ & $\mathrm{R}^{2}$ & $\mathrm{a}$ & $\lambda$ & $\mathrm{Cp}$ \\
$\left(\mathrm{kg} / \mathrm{m}^{3}\right)$ & $(\mathrm{W} /(\mathrm{m} \cdot \mathrm{K}))$ & & $\begin{array}{c}\lambda \\
(\mathrm{m} / \mathrm{s})\end{array}$ & $(\mathrm{W} /(\mathrm{m} \cdot \mathrm{K}))$ & $(\mathrm{J} /(\mathrm{m} \cdot \mathrm{K}))$ \\
\hline
\end{tabular}




\begin{tabular}{cc|c|cc|ccc}
\hline \multirow{2}{*}{ CHLP } & $\begin{array}{c}\text { Average value } \\
\text { standard } \\
\text { deviation }\end{array}$ & 733 & 0.1963 & 0.9979 & 0.2466 & 0.1795 & 996 \\
& $\begin{array}{c}\text { Var. Coef. (\%) } \\
\text { Var. }\end{array}$ & 1.0 & 0.0044 & 0.0047 & 0.0099 & 0.0046 & 55 \\
\hline \multirow{2}{*}{ THLP } & $\begin{array}{c}\text { Average } \\
\text { standard } \\
\text { deviation }\end{array}$ & 887 & 0.2364 & 0.9966 & 0.2277 & 0.2142 & 1009 \\
& $\begin{array}{c}\text { Var. Coef. (\%) } \\
\text { Var. }\end{array}$ & 1.6 & 0.0082 & 0.0034 & 0.0066 & 0.0057 & 63 \\
\hline
\end{tabular}

\section{Effect of temperature on moisture buffer value and on thermal properties}

\subsection{Moisture Buffer Value}

Figure 7 gives the moisture buffer value of the two studied hemp-lime plasters versus temperature.

For the two studied materials, the moisture buffer value increases linearly with temperature. For the CHLP, the moisture buffer value increases by $59 \%$ from $0.67 \mathrm{~g} /\left(\mathrm{m}^{2} . \% \mathrm{RH}\right)$ at $11^{\circ} \mathrm{C}$ to $1.23 \mathrm{~g} /\left(\mathrm{m}^{2} . \% \mathrm{RH}\right)$ at $23^{\circ} \mathrm{C}$. The THLP shows a similar increase of MBV with temperature: the moisture buffer value increases by $54 \%$ from $0.94 \mathrm{~g} /\left(\mathrm{m}^{2} . \% \mathrm{RH}\right)$ at $11^{\circ} \mathrm{C}$ to $1.64 \mathrm{~g} /\left(\mathrm{m}^{2} . \% \mathrm{RH}\right)$ at $23^{\circ} \mathrm{C}$.

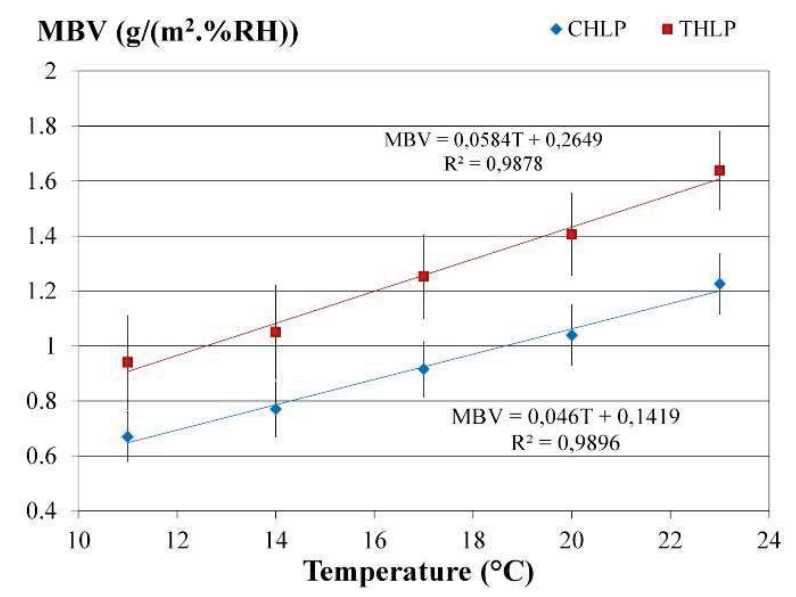

Fig. 7. Effect of temperature on the Moisture Buffer Value of the two hemp-lime plasters. 
The increase of MBV with temperature is partially explained by the increase of the vapour pressure. Actually the MBV is calculated from the relative humidity value which depends on temperature. The corrected moisture buffer value is thus calculated versus vapour pressure $\mathrm{MBV}^{\prime}\left(\mathrm{g} /\left(\mathrm{m}^{2} . \mathrm{Pa}\right)\right)$. The variation of MBV' is given figure 8. This corrected moisture buffer value decreases with temperature. This shows that other parameters, depending on temperature, also play a role as the MBV' is not constant.

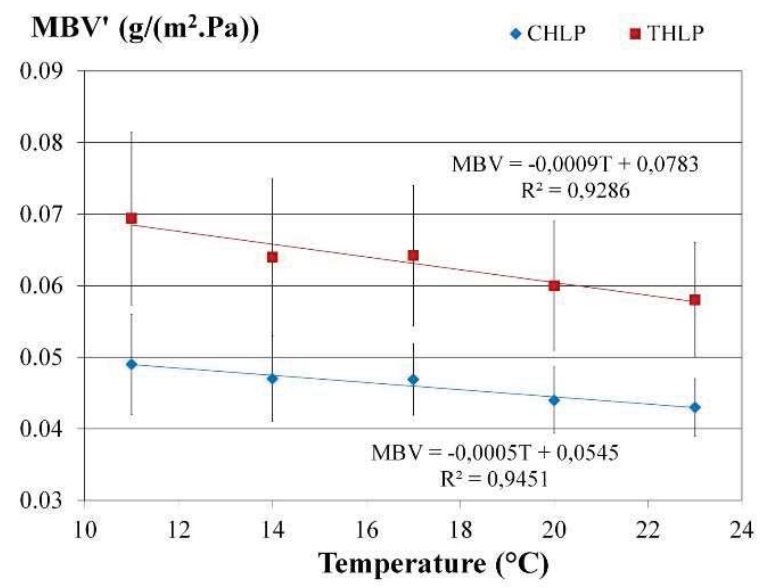

Fig. 8. Effect of temperature on the corrected Moisture Buffer Value of the two hemp-lime plasters.

Actually, the moisture buffering capacity depends both on moisture transfer and storage.

The temperature impacts moisture transfer through several ways. On one hand, under temperature gradient, the moisture moves by thermo-diffusion. In building physics, the effect of temperature on themo-diffusion is negligible as shown in [40]. Furthermore, in this study, there was no temperature gradient during the tests. On the other hand, increase in temperature results in acceleration of transport phenomena. This can be explained by (i) the decrease in drained pore radius for given relative humidity, and (ii) the decrease of water viscosity which increases the liquid permeation at high humidity, [41]. In the range of temperature investigated in this study, these phenomena can be considered as negligible.

On storage point of view, several studies have shown that temperature affects the sorption curve shape [42] [43] [44]. For a given relative humidity, the water content of the material decreases when temperature increases. This phenomenon is mainly due to thermodynamical evolution of physisorption processes [45] [44]. Actually, the adsorption process being exothermic, an increase in temperature limits 
the physical process of adsorption and reduces the number of adsorbed molecules, and thus the water content. Furthermore, when temperature increases, the capillary condensation threshold at pore level also increases. This induces, for a given relative humidity, a decrease in water content. Conversely, an increase in temperature facilitated the desorption process. Thus, an increase in temperature also induces a decrease of the hysteresis as shown in [46]. The storage capacity is thus reduced when temperature increases. This effect would explain the decrease of the corrected moisture buffer value with temperature increase.

\subsection{Thermal properties}

Figure 9 and figure 10 give the variation of thermal conductivity with temperature at dry state and at wet state respectively. Like previously, the coefficient of variation between measurements are very low (lower than 3\% for CHLP and than 4\% for THLP at wet state).

At dry state, for the two hemp-lime plasters, the temperature does not impact the thermal conductivity in the range of temperature from $10^{\circ} \mathrm{C}$ to $40^{\circ} \mathrm{C}$. The average value of thermal conductivity at dry state is thus $0.204 \mathrm{~W} /(\mathrm{m} . \mathrm{K})$ for CHLP and $0.238 \mathrm{~W} /(\mathrm{m} . \mathrm{K})$ for THLP in this range of temperature. At wet state, the value of the thermal conductivity decreases linearly with temperature.

These results are quite surprising as usually the thermal conductivity increases with temperature. For example, Tandiroglu [47] showed that the thermal conductivity of raw perlite aggregate concrete increases with temperature in the range from $-10^{\circ} \mathrm{C}$ to $+70^{\circ} \mathrm{C}$. The increase of thermal conductivity with temperature was also observed on bio-based materials: Vololonirina [48] showed that the thermal conductivity of wood-based products scaled linearly with temperature between $10^{\circ} \mathrm{C}$ and $40^{\circ} \mathrm{C}$. 


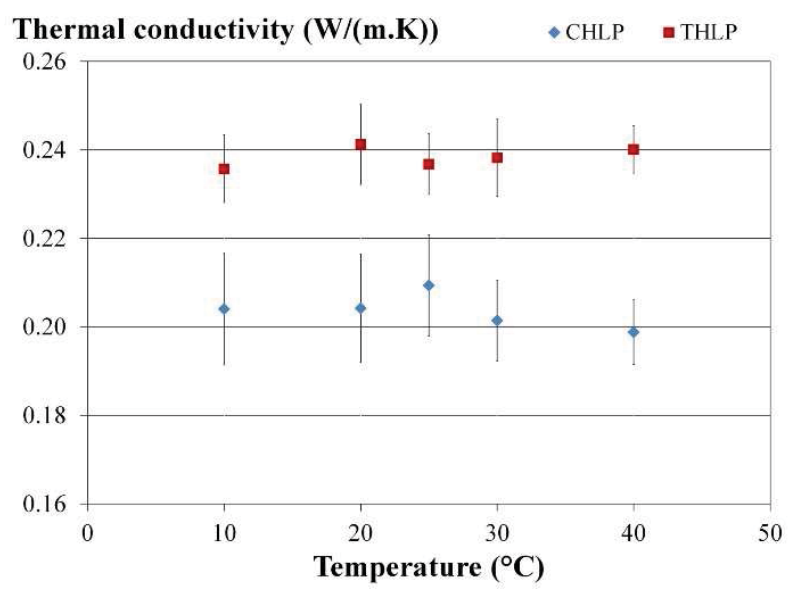

Fig. 9. Effect of temperature on the thermal conductivity at dry state of the two hemp-lime plasters (hot wire).

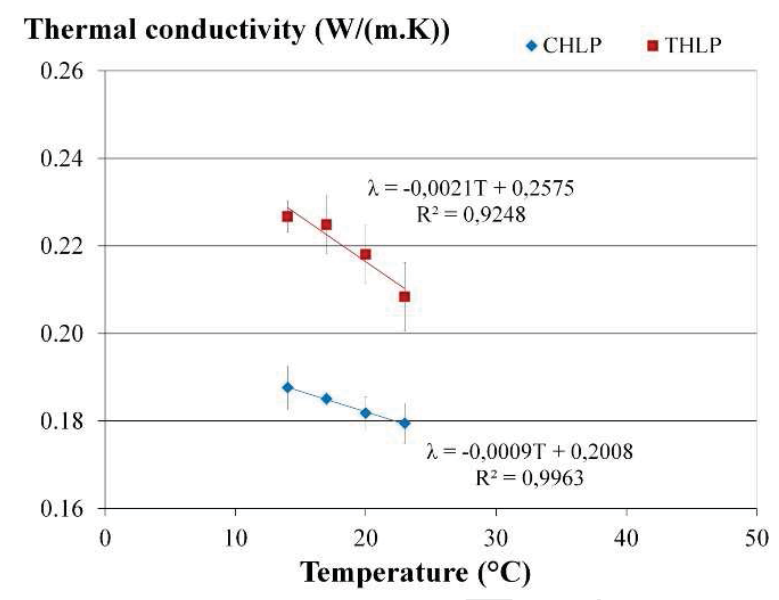

Fig. 10. Effect of temperature on the thermal conductivity at wet state (50\%RH) of the two hemp-lime plasters (hot disk).

Moreover, during the experimental study, it was observed that the specimens mass increased when the temperature decreased. In fact, their water content increases when temperature decreases (Fig. 11). Actually, sorption curve gets higher when temperature decreases. So, for a given relative humidity, the water content increases when the temperature decreases. This increase in water content induces an increase in thermal conductivity. Actually, whatever the nature of the material, the thermal conductivity increases with water content. This was observed in several studies on various materials such as brick, 
autoclaved aerated concrete, lime plaster, hemp concrete, thermal insulation or even high performance concrete [17] [49] [50] [39] [51]. Thermal characteristics are thus studied versus water content.

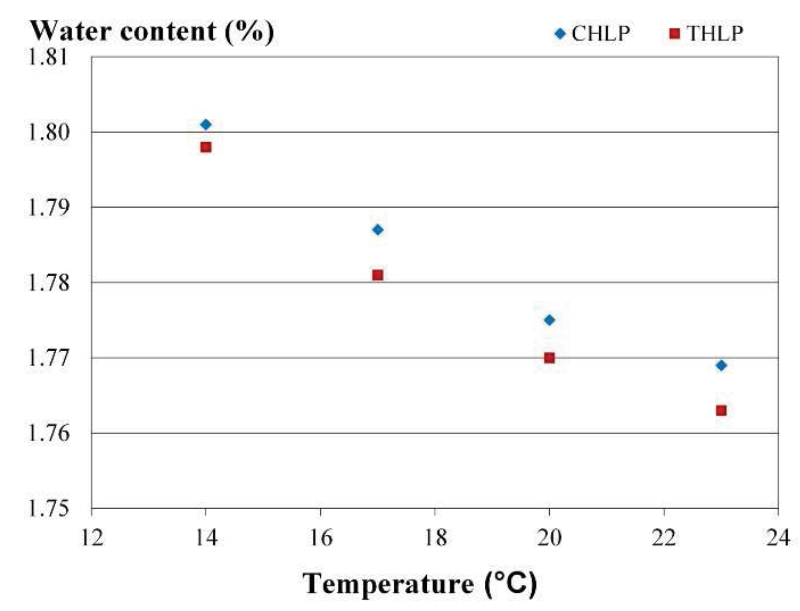

Fig. 11. Effect of temperature on the water content at 50\%RH of the two hemp-lime plasters.

Figure 12 gives the variation of thermal conductivity with water content for the two types of hemp-lime plasters. Both CHLP and THLP show an increase of thermal conductivity with water content. For the CHLP, the thermal conductivity increases by $4.5 \%$ from $0.179 \mathrm{~W} /(\mathrm{m} \mathrm{k})$ at $1.77 \%$ in water content to $0.188 \mathrm{~W} /(\mathrm{m} \mathrm{k})$ at $1.80 \%$ in water content. For the THLP, the thermal conductivity rises by $8.4 \%$ from $0.208 \mathrm{~W} /(\mathrm{m} \mathrm{k})$ at $1.76 \%$ to $0.227 \mathrm{~W} /(\mathrm{m} \mathrm{k})$ at $1.8 \%$ in water content.

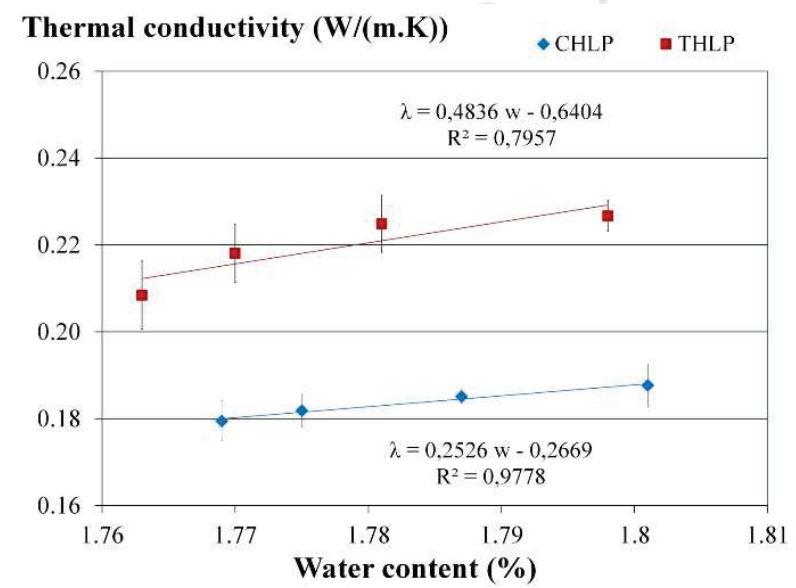

Fig. 12. Effect of water content on thermal conductivity of the two hemp-lime plasters. 
Figure 13 gives the variation of thermal diffusivity with water content when water content ranges from 1.76 to $1.80 \%$. The results are homogeneous for each point, with coefficient of variation about 5\%. THLP shows more scattered results when the water content is $1.80 \%$. For this point the coefficient of variation is $10 \%$. The two hemp-lime plasters show similar value of thermal diffusivity when water content is lower than $1.79 \%$. The CHLP shows an increase of thermal diffusivity with water content. Its diffusivity ranges from 0.25 to $0.30 \mathrm{~mm}^{2} / \mathrm{s}$. The thermal diffusivity of THLP ranges from 0.23 to $0.27 \mathrm{~mm}^{2} / \mathrm{s}$, with a maximal value when the moisture content is $1.78 \%$. This variation is similar to the one given by Taoukil for wood concrete [39]. For CHLP, the maximal value of diffusivity would probably appear for higher value of water content. As Taoukil state, the variation of thermal diffusivity with water content depends on the relative variations of thermal conductivity and of volumetric heat capacity. When the thermal conductivity increases faster than the volumetric heat capacity, the thermal diffusivity increases. When the thermal conductivity increases slower than the volumetric heat capacity, the thermal diffusivity decreases.

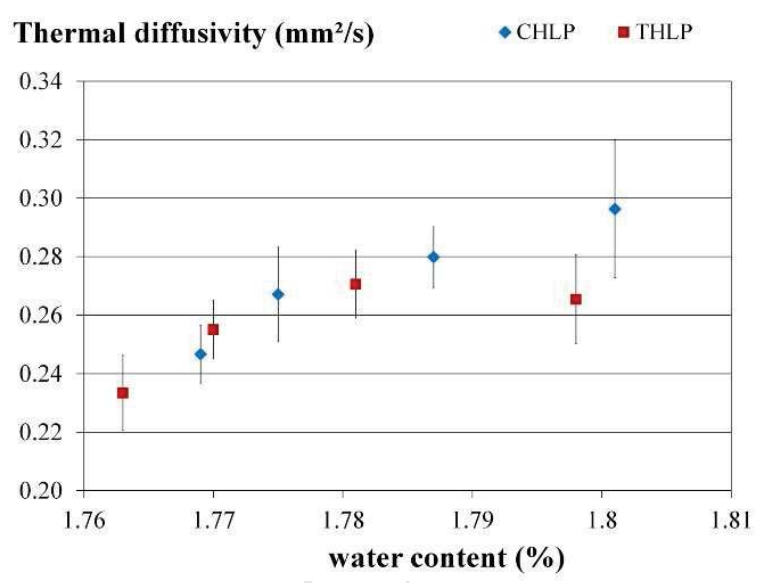

Fig. 13. Effect of water content on thermal diffusivity of the two hemp-lime plasters.

\section{Conclusions}

This study provides hygric and thermal properties of two hemp-lime plasters which differ from their size of hemp shiv. The two hemp-lime plasters show medium density (about 720 to $880 \mathrm{~kg} / \mathrm{m}^{3}$ ) due to the use of hemp shiv which induces high porosity. Thus, the two hemp-lime plasters are hygroscopic and show 
high water vapour permeability. According to the Nordtest classification, the two hemp-lime plasters are good hygric regulators. Their moisture buffer value is twice the value of gypsum. From thermal point of view, the thermal conductivity of hemp-lime plasters is about $0.2 \mathrm{~W} /(\mathrm{m} . \mathrm{K})$, much lower than the value of gypsum (about 0.48 to $0.80 \mathrm{~W} /(\mathrm{m} . \mathrm{K})$ ).

It is shown that the size of hemp shiv slightly impacts hygric and thermal properties of hemp-lime plasters in link with the effect on density due to the intermingling of hemp shiv. Furthermore, it is shown that temperature slightly impacts hygric behaviour and thus thermal characteristics.

So, this study allows highlighting that hemp-lime plasters can be used to improve hygric and thermal performances of walls, in order to reduce energy consumption and to improve hygric and thermal comfort. The moisture penetration depth, found in this study, is about 6 to $7 \mathrm{~cm}$. So, to fully benefit from the moisture buffering capacity of hemp-lime plasters, their thickness should be of this magnitude. If the thickness is lower, the moisture buffering capacity of the wall also depends on the type of background which is plastered.

Moreover, the measured properties can be used as input data for numerical modelling of hygrothermal behaviour of building envelop.

Finally, hemp-lime plasters can be coated (with limewash for example). In such case, the hygric performances of coated hemp-lime plasters should be assessed.

\section{Acknowledgments}

This work follows the French national project ANR-06-MAPR-0002 "Béton de chanvre" - Programme MAPR 2006 and the Breton regional project "PRIR Ecomatx".

\section{References}

[1] Maravelaki-Kalaitzaki, P.; Bakolas, A.; Moropoulou, A.; Physico-chemical study of Cretan ancient mortars. Cem Concr Res 2003;33:651-61. 
[2] M. Karoglou, A. Moropoulou, M.K. Krokida, Z.B. Maroulis, A powerful simulator for moisture transfer in buildings, Building and Environment, 42, pp 902-912, 2007.

[3] ] E.Vejmelková,; M. Keppert; Sovják, R Černý, Mechanical, thermal and hygric properties of limepozzolana plasters for historical buildings, Thermophysics 2010 proceedings, pp 314-320, 2010.

[4] E. Vejmelková, D. Kon áková, M. Čáchová, M. Keppert, R. Černy, Effect of hydrophobization on the properties of lime-metakaolin plasters, Construction and Building Materials, 37, pp 556-561, 2012. http://dx.doi.org/10.1016/j.conbuildmat.2012.07.097

[5] M. Lanzón, P.A. García-Ruiz, Evaluation of capillary water absorption in rendering mortars made with powdered waterproofing additives, Construction and Building Materials, 23, pp 3287-3291, 2009. [6] S. Barberoa, M. Duttob, C. Ferruab, A. Pereno, Analysis on existent thermal insulating plasters towards innovative applications: Evaluation methodology for a real cost-performance comparison, Energy and Buildings, 77, pp 40-47, 2014.

[7] A. Cherki, B. Remy, A. Khabbazi, Y. Jannot, D. Baillis, Experimental thermal properties characterization of insulating cork-gypsum composite, Construction and Building Materials , 54, pp 202209, 2014.

[8] L. Agullo' , A. Aguado, T. Garcia, Study of the use of paper manufacturing waste in plaster composite mixtures, Building and Environment, 41,pp 821-827, 2006. doi:10.1016/j.buildenv.2005.03.011

[9] L. Bianco, V. Serra, S. Fantucci, M. Dutto, M. Massolino, Thermal insulating plaster as a solution for refurbishing historic building envelopes: First experimental results, Energy and Buildings, 95, pp 86-91, 2015. http://dx.doi.org/10.1016/j.enbuild.2014.11.016[

[10] H. Zhang, H. Yoshino, K. Hasegawa, Assessing the moisture buffering performance of hygroscopic material by using experimental method, Building and Environment, 48, pp 27-34, 2012.

[11] M. Maddison, T. Mauring, K. Kirsimäe, U. Mander, The humidity buffer capacity of clay-sand plaster filled with phytomass from treatment wetlands, Building and Environment, 44, pp 1864-1868, 2009. doi:10.1016/j.buildenv.2008.12.008

[12] E.K. Darling, C.J. Cros, P. Wargocki, J. Kolarik, G.C. Morrison, R.L. Corsi, Impacts of a clay plaster on indoor air quality assessed using chemical and sensory measurements, Building and Environment, 57, pp 370-376, 2012. http://dx.doi.org/10.1016/j.buildenv.2012.06.004 
[13] S. Amziane, L. Arnaud, Bio-aggregate-based Building Materials, Applications to Hemp Concrete. ISTE Ltd and John Wiley \& Sons, Inc, 2013.

[14] M.-P. Boutin, C. Flamin, S. Quinton, G. Gosse, Etude des caractéristiques environnementales du chanvre par l'analyse de son cycle de vie (in French), INRA Lille, France, 2005.

[15] V. Cerezo.; Propriétés mécaniques, thermiques et acoustiques d’un matériau à base de particules végétales: approche expérimentale et modélisation théorique. Ecole Nationale des Travaux Publics de l’Etat, Institut National des Sciences Appliquées de Lyon, 2005, in french.

[16] F. Collet, S. Prétot, Experimental investigation of moisture buffering capacity of sprayed hemp concrete., Construction and Building Materials, 36, pp 58-65, 2012.

[17] F. Collet, S. Prétot., Thermal conductivity of hemp concretes: variation with formulation, density and water content, Construction and Building Materials, 65, pp 612-619, 2014, DOI information: 10.1016/j.conbuildmat.2014.05.039

[18] A. Evrard, Sorption behaviour of Lime-hemp concrete and its relation to indoor comfort and energy demand. In: 23rd Conference on passive and low energy architecture, Geneva, Switzerland; 6-8, 2006. [19] S. Prétot, F. Collet, C. Garnier; Life Cycle Assessment of a hemp concrete wall: impact of thickness and coating, Building and Environment 72C, pp. 223-231, 2014. DOI information: 10.1016/j.buildenv.2013.11.010.

[20] A.D. Tran Le, C. Maalouf, T.H. Mai, E. Wurtz, F. Collet, Transient hygrothermal behaviour of a hemp concrete building envelope. Energy and Buildings 42, 1797-1806, 2010.

[21]. International Union of Pure and Applied Chemistry. Reporting physisorption data for Gas/solid systems with special reference to the determination of surface area and porosity. Pure and Applied Chemistry, Vol. 57, N4, pp 603-619, 1986.

[22] Brunauer S., Emmet P.H., Teller E., Adsorption of gases in multimolecular layers, Journal of the American Chemical Society, vol; 60, pp 309-319, 1938.

[23]. Barett E.P., Joyner L.G., Halenda P.P., The determination of pore volume and area distributions in porous substances - I computations from nitrogen isotherms, Journal of American Chemical Society, 73 (1951), 373-380. 
[24] EA. Guggenheim, Application of statistical mechanics. Oxford: Clarendon Press; 1966 [chapter 11].

[25] RB. Anderson, Modifications of the brunauer, emmett and teller. J Am Chem Soc 68(4) (1946), 686691.

[26] RB. Anderson, WK. Hall, Modifications of the brunauer, emmett and teller, equation II. J Am Chem Soc 70(5) (1948), 1727-1734.

[27] JH. De Boer, The dynamical character of adsorption. Oxford: Clarendon Press;1953.

[28] C. Rode, Moisture buffering of Building Materials, Report BYG·DTU R-126, 2005, ISSN 1601 2917, ISBN 87-7877-195.

[29] J. Arfvidsson, Moisture penetration for periodically varing relative humidity at boundary, acta physica aedificiorum, vol 2.

[30] F. Collet, J. Chamoin, S. Pretot, C. Lanos, Comparison of the hygric behaviour of three hemp concretes, Energy and Buildings, 62, pp 294-303, 2013.

[31] J Hladik, “Métrologie des propriétés thermophysiques des matériaux”, Masson collection mesures physiques, 1990.

[32] J. BEAR, "Dynamics of fluids in porous media", American Elsevier Publishing Company, New York, 1972.

[33] H. Derluyn, D. Derome, J. Carmeliet, E. Stora, R. Barbarulo, Hysteretic moisture behavior of concrete: modelling and analysis, Cement and Concrete Research, vol 42, p 1379-1388, 2012.

[34] A.D. Tran Le, Etude des transferts hygrothermiques dans le béton de chanvre et leur application au bâtiment. PhD thesis, Université de Reims Champagne- Ardenne; November 2010 [in French].

[35] S. Pretot, F. Collet, P. Glouannec, V. Lang, Variation des propriétés thermiques de bétons de chanvre en fonction de la formulation (in French), Congrès français de thermique-Efficacité énergétique, Vannes 2009, Tome 2, pp 865-870, Editions Société Française de Thermique, ISBN: 2-905267-67-2.

[36] E. Vejmelková, D. Koňáková, M. Čáchová, M. Keppert, M., R. Černý, Effect of hydrophobization on the properties of lime-metakaolin plasters. Construction and Building Materials 37, 556-561, 2012. 
[37] E. Agoua. E. Allognon-Houessou, E. Adjovic, B. Togbedji; Thermal conductivity of composites made of wastes of wood and expanded polystyrene, Construction and Building Materials ,41, pp 557562, 2013.

[38] Al Rim, K.; Ledhem, A.; Douzane, O.; Dheilly, R.M.; Queneudec, M.; Influence of the proportion of wood on the thermal and mechanical performances of clay-cement-wood composites, Cement \& Concrete Composites, 21, pp 269-276, 1999.

[39] D. Taoukil; A. El bouardi, F. Sick, A Mimet; H. Ezbakhe; T. Ajzoul.; Moisture content influence on the thermal conductivity and diffusivity of wood-concrete composite, Construction and Building Materials, 48, pp 104-115, 2013.

[40] H. Janssen, Thermal diffusion of water vapour transport in porous materials : Fact or fiction ?, International Journal of Heat and Mass transfer, vol 54, pp 1548-1562, 2011.

[41] F. Brue, Rôles de la temperature et de la composition sur le couplage thermos-hydro-mécanique du béton, Thèse de doctorat, Ecole central de Lille, France, 2009.

[42] Daïan J.F., 1988, Condensation and isothermal water transfer in cement mortar Part I - Pore size distributio, equilibrium water condensation and imbibition, Transport in Porous Media, vol 3, nº, p 563589, 1988.

[43] Wood and cellulose science, Ronald Press, New York, Etats-Unis, 1964.

[44] Merakeb S., Dubois F., Petit C., 2008, Modélisation des hystérésis de sorption dans les matériaux hygroscopiques, Comptes Rendus de Mécanique, vol 337, p 34-39, 2008

[45] Poyet S., Charles S., 2009, Temperature dependence of the sorption isotherms of cementedbased materials : heat of sorption and Clausius-Clapeyron formula, Cement and Concrete Research, vol 39, n¹1, p 1060-1067, 2009. 
[46] Ishida T., Maekawa K., Kishi T., 2007, Enhanced modeling of moisture equilibrium and transport in cementitious materials under arbitrary temperature and relative humidity history, Cement and Concrete Research, vol 37, n4, p 565-578, 2007.

[47] A. Tandiroglu, Temperature-Dependent Thermal Conductivity of High Strength Lightweight Raw Perlite Aggregate Concrete, Int J Thermophys, 31, p 1195-1211, 2010.

[48] O. Vololonirina, M. Coutand, B. Perrin, Characterization of hygrothermal properties of wood-based products - Impact of moisture content and temperature. Construction and Building Materials. 63, (Jul. 2014), 223-233.

[49] M. Jerman, R. Černý, Effect of moisture content on heat and moisture transport and storage properties of thermal insulation materials. Energy and Buildings. 53, (Oct. 2012), 39-46, 2012.

[50] Z. Pavlík, F. Fiala; E. Vejmelková, R. Cerný, Application of Effective Media Theory for Determination of Thermal Properties of Hollow Bricks as a Function of Moisture Content. International Journal of Thermophysics. 34, 5 (May 2013), 894-908.

[51] M.I. Khan, Factors affecting the thermal properties of concrete and applicability of its prediction models, Building and Environment, vol. 37, p 607 - 614, 2002. 
Tab. 1: Composition of the studied hemp-lime plasters

\begin{tabular}{ccccc}
\hline Material & Notation & Binder & Hemp shiv & $\begin{array}{c}\text { Hemp/binder mass } \\
\text { ratio }\end{array}$ \\
\hline $\begin{array}{c}\text { Chanvribat } \\
\text { hemp-lime plaster } \\
\begin{array}{c}\text { Terrachanvre } \\
\text { hemp-lime plaster }\end{array}\end{array}$ & CHLP & $\begin{array}{c}\text { Tradichanvre } \\
\text { The based binder } \\
\text { Tradichanvre } \\
\text { lime based binder }\end{array}$ & $\begin{array}{c}\text { Chanvribat } \\
\text { defibered hemp shiv } \\
\text { Terrachanvre F } \\
\text { defibered hemp shiv }\end{array}$ & 0.15 \\
\hline
\end{tabular}

Tab. 2: Physical properties of the studied hemp-lime plasters

\begin{tabular}{cccc}
\hline & $\begin{array}{c}\text { Density } \\
\left(\mathrm{kg} / \mathrm{m}^{3}\right)\end{array}$ & $\begin{array}{c}\text { Total } \\
\text { porosity } \\
(\%)\end{array}$ & $\begin{array}{c}\text { Open } \\
\text { porosity } \\
(\%)\end{array}$ \\
\hline CHLP & $723 \pm 8.8$ & 72 & 65.5 \\
THLP & $881 \pm 16.5$ & 65.9 & 64.2 \\
\hline
\end{tabular}

Tab. 3. Sorption curves: Fitting parameters of the GAB model for the two hemp-lime plasters

\begin{tabular}{cccc}
\hline & $w_{m}(\mathrm{~kg} / \mathrm{kg})$ & $C_{G}$ & $k$ \\
\hline CHLP & 0.00455 & 10.45 & 0.9854 \\
THLP & 0.00368 & 21.40 & 0.9925 \\
\hline
\end{tabular}

Tab. 4. Variation of water vapour permeability versus relative humidity: parameters of the fitting power-law relationship (Eq.(6)) for the two hemp-lime plasters.

\begin{tabular}{cccc}
\hline & \multicolumn{1}{c}{ A } & B & C \\
\hline CHLP & $2.85 \mathrm{E}-11$ & $4.71 \mathrm{E}-11$ & 1.655 \\
THLP & $1.63 \mathrm{E}-11$ & $4.43 \mathrm{E}-11$ & 1.971 \\
\hline
\end{tabular}




\section{ACCEPTED MANUSCRIPT}

Tab. 5. Moisture Buffer Value in adsorption, desorption and average for the two hemp-lime plasters

\begin{tabular}{cccc}
\hline & $\begin{array}{c}\text { MBV ads. } \\
\left(\mathrm{g} /\left(\mathrm{m}^{2} . \% \mathrm{RH}\right)\right)\end{array}$ & $\begin{array}{c}\text { MBV des. } \\
\left(\mathrm{g} /\left(\mathrm{m}^{2} . \% \mathrm{RH}\right)\right)\end{array}$ & $\begin{array}{c}\text { MBV av. } \\
\left(\mathrm{g} /\left(\mathrm{m}^{2} . \% \mathrm{RH}\right)\right.\end{array}$ \\
\hline CHLP & 1.18 & 1.27 & 1.23 \\
THLP & 1.59 & 1.68 & 1.64 \\
\hline
\end{tabular}

Tab. 6: Thermal properties of materials at $23{ }^{\circ} \mathrm{C}, 50 \% \mathrm{RH}$

\begin{tabular}{|c|c|c|c|c|c|c|c|}
\hline & & \multicolumn{4}{|c|}{ Hot Wire } & \multicolumn{2}{|l|}{ Hot Disk } \\
\hline & & $\begin{array}{c}\rho \\
\left(\mathrm{kg} / \mathrm{m}^{3}\right)\end{array}$ & $\begin{array}{c}\lambda \\
(\mathrm{W} /(\mathrm{m} \cdot \mathrm{K}))\end{array}$ & $\mathrm{R}^{2}$ & $\begin{array}{c}\mathrm{a} \\
\left(\mathrm{mm}^{2} / \mathrm{s}\right)\end{array}$ & $\begin{array}{c}\lambda \\
(\mathrm{W} /(\mathrm{m} \cdot \mathrm{K}))\end{array}$ & $\begin{array}{c}\mathrm{Cp} \\
(\mathrm{J} /(\mathrm{m} \cdot \mathrm{K}))\end{array}$ \\
\hline \multirow{3}{*}{ CHLP } & Average value & 733 & 0.1963 & 0.9979 & 0.2466 & 0.1795 & 996 \\
\hline & $\begin{array}{c}\text { standard } \\
\text { deviation }\end{array}$ & 7 & 0.0044 & 0.0047 & 0.0099 & 0.0046 & 55 \\
\hline & Var. Coef. (\%) & 1.0 & 2.2 & - & 4 & 2.6 & 5.5 \\
\hline \multirow{3}{*}{ THLP } & Average & 887 & 0.2364 & 0.9966 & 0.2277 & 0.2142 & 1009 \\
\hline & $\begin{array}{c}\text { standard } \\
\text { deviation }\end{array}$ & 14 & 0.0082 & 0.0034 & 0.0066 & 0.0057 & 63 \\
\hline & Var. Coef. (\%) & 1.6 & 3.5 & - & 2.9 & 2.7 & 6.2 \\
\hline
\end{tabular}


$\operatorname{MBV}\left(\mathrm{g} /\left(\mathrm{m}^{2} . \% \mathrm{RH}\right)\right)$

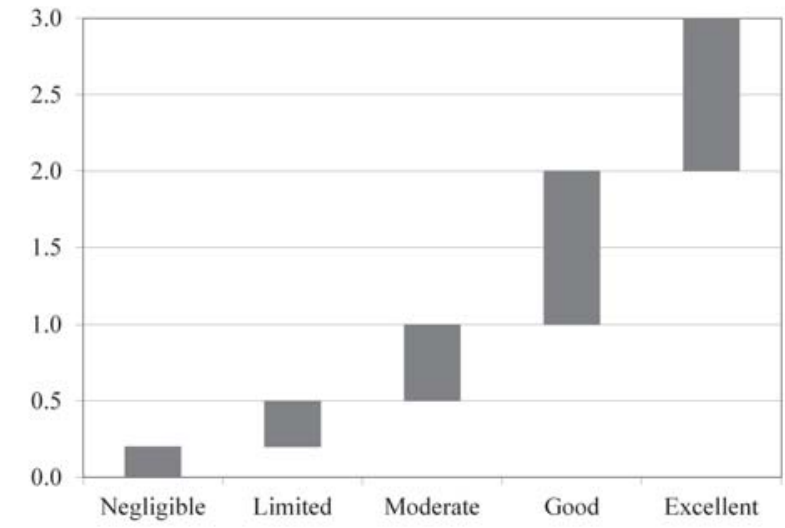




\section{ACCEPTED MANUSCRIPT}
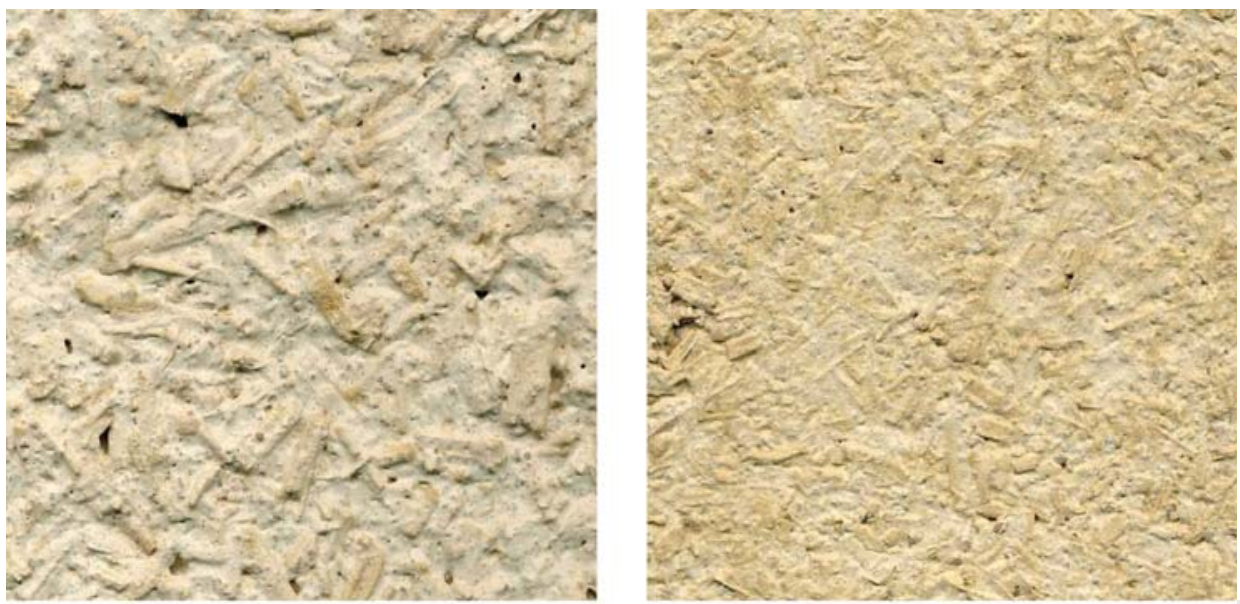

$1 \mathrm{~cm}$ 


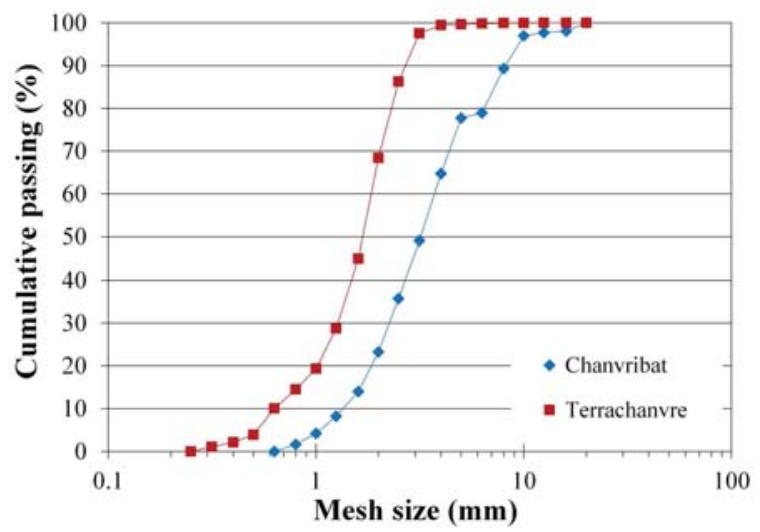




\section{ACCEPTED MANUSCRIPT}
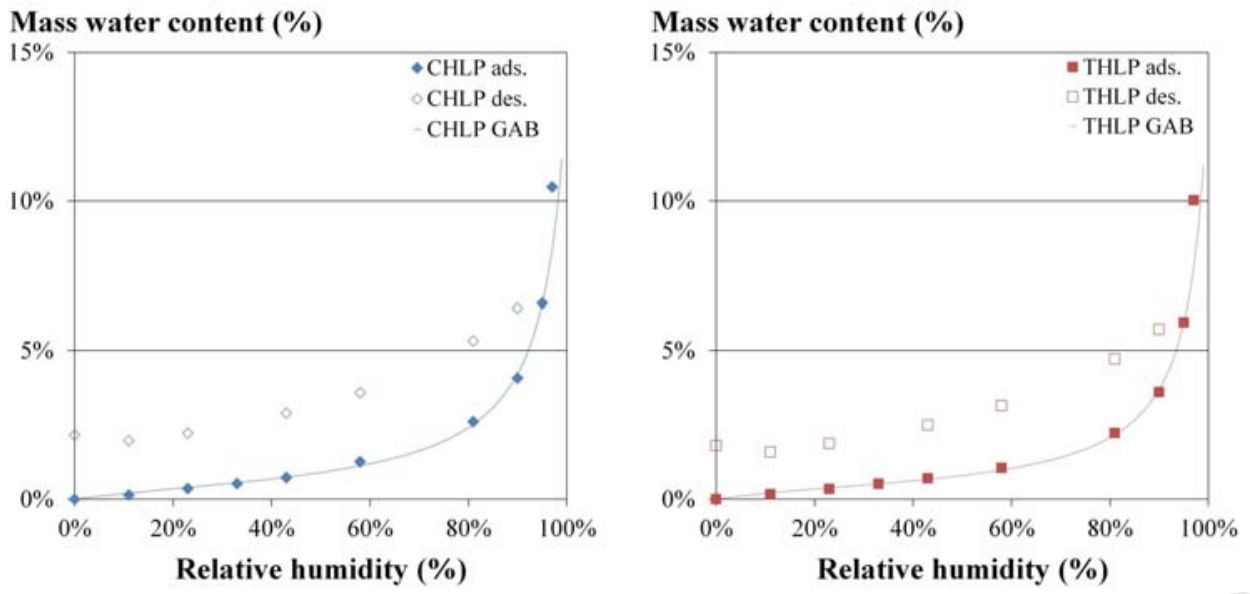


\section{ACCEPTED MANUSCRIPT}
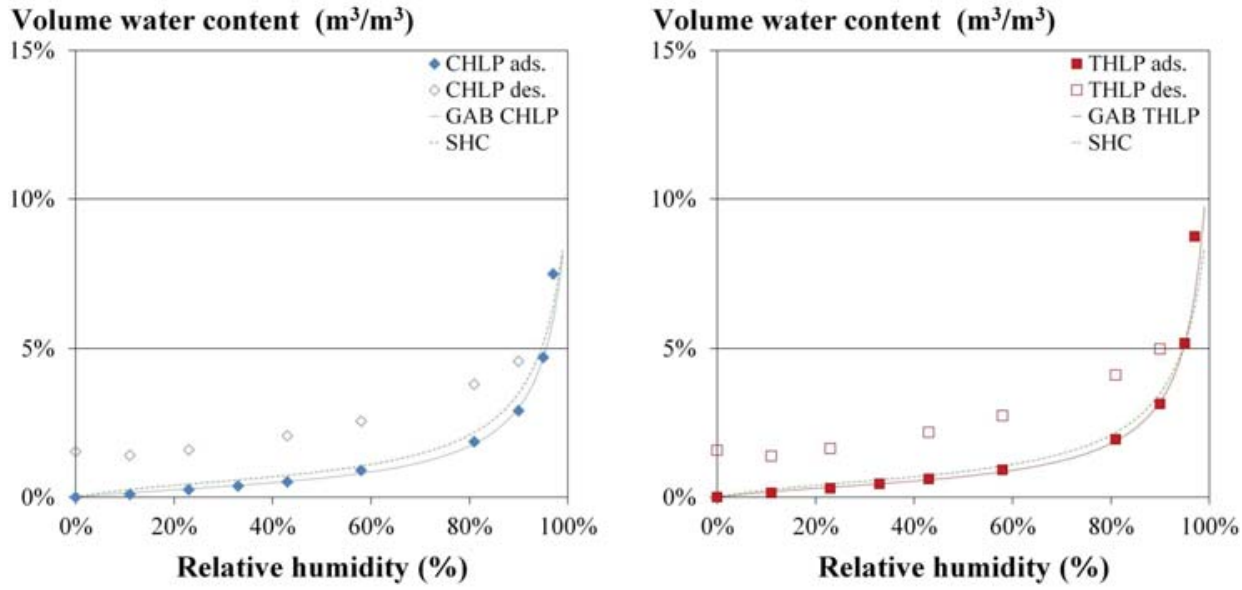
Water vapour permeability $(\mathrm{kg} /(\mathrm{m} . \mathrm{s.Pa}))$

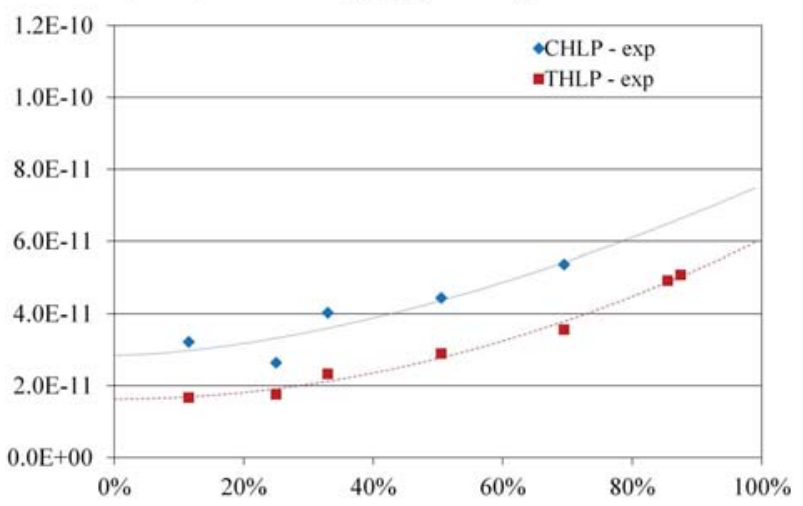

Relative Humidity (\%) 


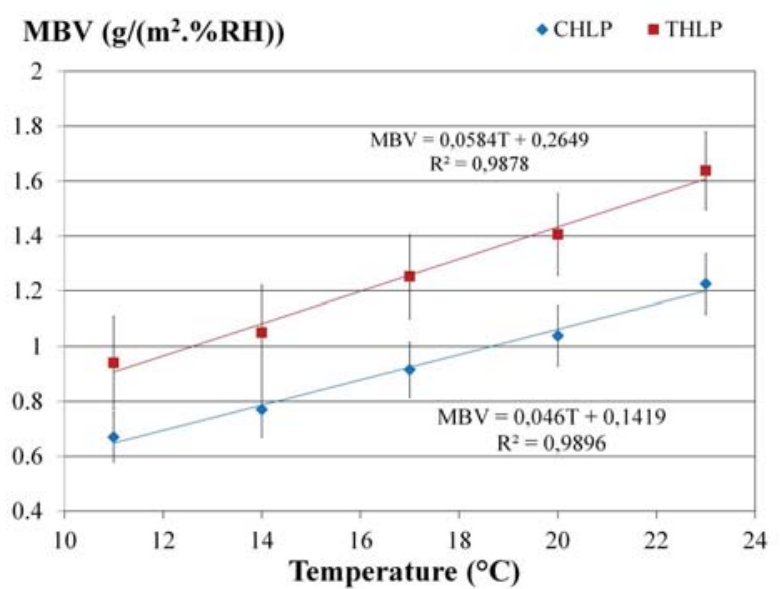




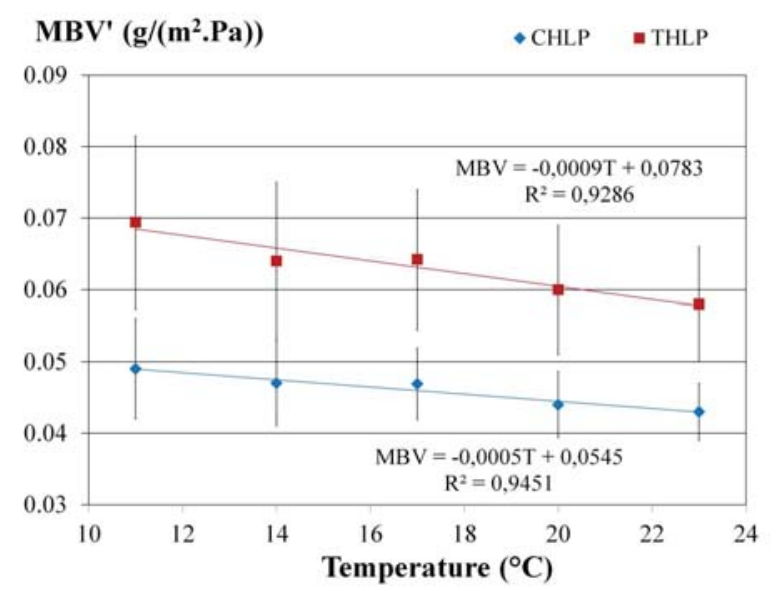




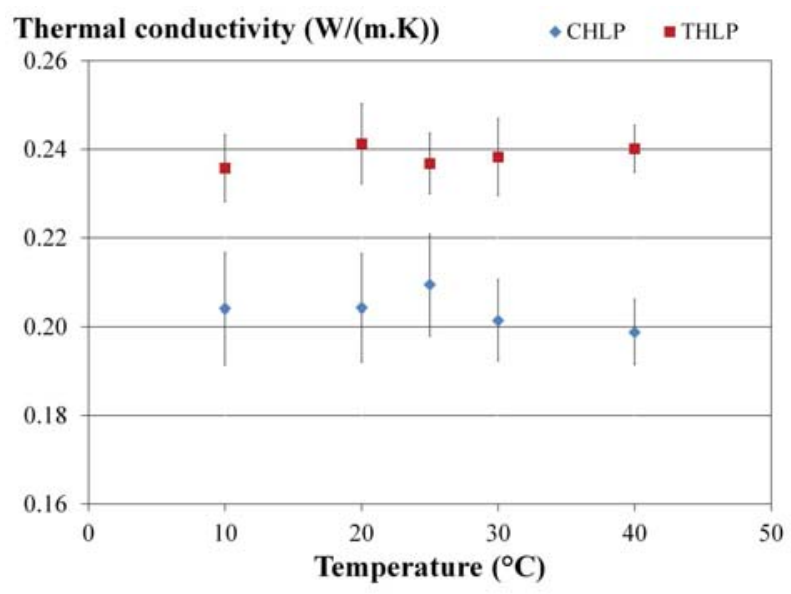


Thermal conductivity $(\mathrm{W} /(\mathbf{m} . \mathrm{K}))$

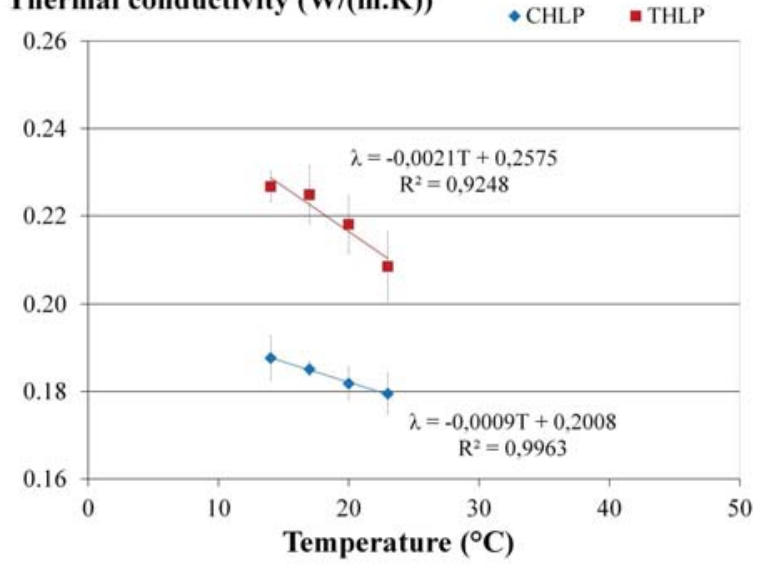




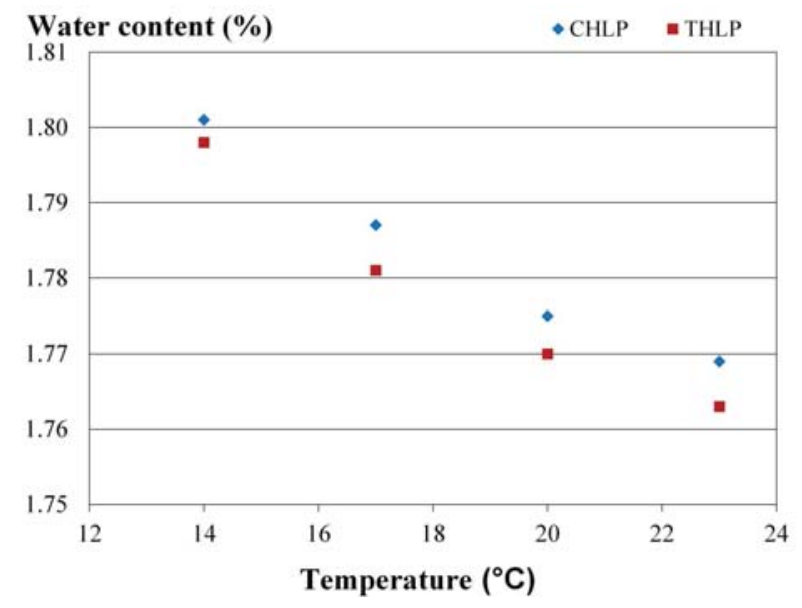




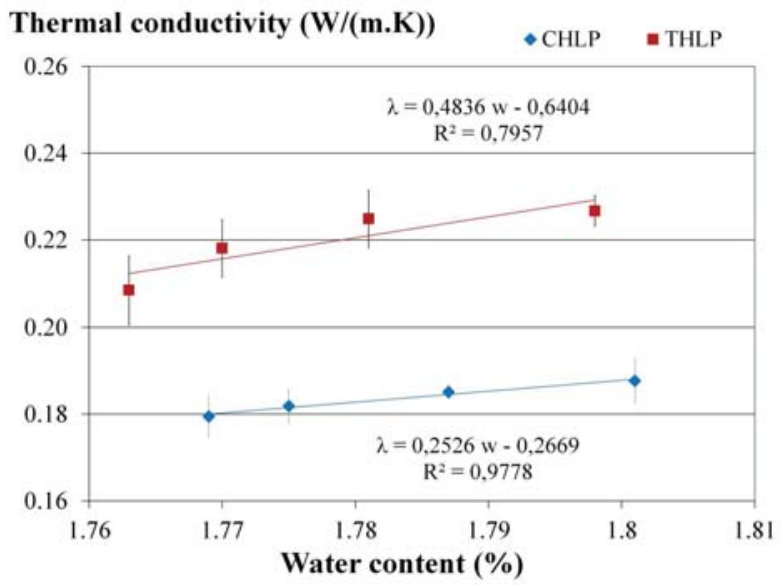




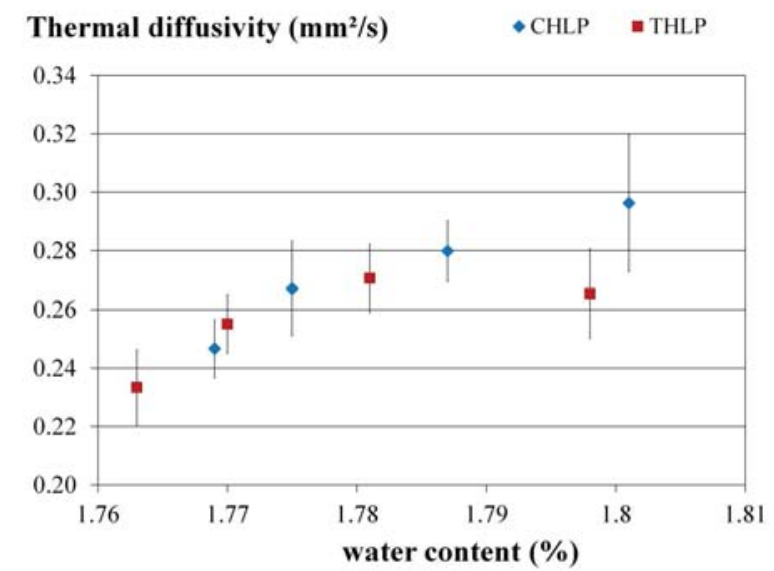




\section{ACCEPTED MANUSCRIPT}

- Hygric and thermal properties of Hemp-lime plasters are investigated.

- Hemp-lime plasters are good hygric regulators.

- The moisture penetration depth is estimated.

- Hemp-lime plasters are pertinent solution for thermal retrofit.

- Effect of temperature on hygric and thermal properties is investigated. 